\title{
La silla vacía: aplicación jurídica y su consecuencia
}

\author{
The Adsent Seat: Legal Application And Its Consequence
}

\begin{abstract}
Julián Giraldo GómeZ*
EdER Hernández LOZANO ${ }^{* *}$

*Abogado. Especialista en Derecho Penal y Criminología, Magister en Derecho Público. Universidad La Gran Colombia Armenia, Quindío

**Especialista en Derecho Administrativo, Magister en Derecho Público. Universidad la Gran Colombia Armenia Quindío

Fecha de recepción: Octubre de 2019 Fecha de aprobación: marzo de 2020

Para citar este artículo / To reference this article La silla vacía: aplicación jurídica y su consecuencia. Inciso, 22(1) ; 27-56.
\end{abstract}

DOI: http://dx.doi.org/10.18634/incj.22v.1i.1029

\section{Resumen}

El artículo analiza la aplicación de la silla vacía por falta temporal o absoluta que no da lugar a remplazo en los cuerpos de elección popular en Colombia y su respectiva consecuencia jurídica, siguiendo el lineamiento sustancial del artículo 134 de la Constitución Política, modificado por el artículo 4 del acto legislativo 02 de 2015. La investigación es de tipo descriptivo analítico e histórico hermenéutico; con enfoque metodológico de tipo crítico social y positivista, basados en las reglas de interpretación del exponente Herbert L. A. Hart, utilizando instrumentos como las normas constitucionales, la ley, la jurisprudencia, los convenios y tratados internacionales para dar respuesta a la tesis: ¿Cuál es la consecuencia jurídica en la aplicación de la figura de la silla vacía en aquellos casos de falta temporal o absoluta en los cuerpos colegiados de elección popular en Colombia? Dilema concentrado en el artículo 134 de la Constitución frente al 23 de la Convención Americana sobre Derechos Humanos, traídos por el bloque de constitucionalidad del artículo 93 de la carta política; dos normas legales vigentes de aplicación en el ordenamiento 
jurídico y cuando se aplica la silla vacía, resalta una vulneración al derecho político de libre representación popular, afectándose las decisiones colegiadas al quedar reducidas a tal punto que pueden lesionar el quórum deliberatorio y decisorio en la corporación colegiada de elección popular. Concluyendo la eliminación de la figura silla vacía por ser contraria al artículo 23 de la citada Convención, armonizándose el Derecho Interno con la Disposición Internacional.

Palabras clave: silla vacía, derechos civiles, vulnerar, sistema político.

\begin{abstract}
The article analyzes the application of the Absent Seat by temporary or absolute foul, that it does not give rise to replacement in the bodies of popular election in Colombia and its respective legal consequence, following the substantial guidelines of article 134 of the Political Constitution, modified by article 4 of legislative act 02 of 2015 . The research is of hermeneutic analytical and historical descriptive type; with a methodological approach of a critical social and positivist type, based on the rules of interpretation of the exponent Herbert L. A. Hart, using investigative instruments such as constitutional norms, law, jurisprudence, international conventions and treaties to respond to the thesis: What is the juridical consequence in the application of the figure of the absent seat in those cases of temporary or absolute foul in the collegiate bodies of popular election in Colombia?; dilemma concentrated in the Article 134 idem in front of the Article 23 of the American Convention on Human Rights, brought by the Constitutionality Block of Article 93 of the Political Charter; two current legal rules of application in the legal system and when the absent seat is applied, highlights an infringement of the civil rights of popular free representation, affecting the collegiate decisions to be reduced to such an extent that they can injure the deliberative and decisive quorum in the corporation Collegiate of popular choice. Concluding the elimination of the absent seat figure because of being contrary to article 23 of the aforementioned Convention, harmonizing the Internal Law with the International Provisio
\end{abstract}

Keywords: absent seat, civil rights, infringement, political system

\title{
Introducción
}

Colombia siendo un Estado democrático y participativo, comprometido a respetar los tratados internacionales pertenecientes al bloque de constitucionalidad y de libre determinación; con una estructura democrática marcada, que permite al pueblo en forma directa hacer parte de las decisiones mediante los mecanismos de elección popular en las corporaciones públicas con el fin de garantizar la representación popular que ejerce el pueblo al participar y elegir a sus representantes mediante el sufragio; nace la representación en los cuerpos colegiados de elección popular en Colombia, la que se ejerce mediante una curul, alusiva a un asiento, silla o lugar que corresponde ocuparla a aquel representante del pueblo elegido por votación popular en los siguientes cuerpos colegiados: Congreso de la República, compuesto por el Senado y la Cámara de Representantes, las asambleas departamentales, los concejos municipales o distritales y las juntas administradoras locales. 
El ciudadano que quiere hacer parte de alguna de las mencionadas corporaciones, postula su nombre y en elecciones libres, puede ser elegido y ocupar una de las curules representando al pueblo en general. El problema radica en que el artículo 134 de la Constitución Política de Colombia, prevé la silla vacía de manera temporal o absoluta, bien sea por los delitos contemplados en el citado artículo e incluso por la orden de captura relacionados con los mismos, siendo estas posiciones más restrictivas y lesivas a las contempladas en el artículo 23 sobre la restricción de derechos políticos de la Convención Americana sobre Derechos Humanos.

Por tratarse de dos normas jurídicas de carácter constitucional vigentes en la legislación colombiana, es menester entrar a determinar la aplicación de estas normas y su consecuencia jurídica en cada una de ellas.

\section{Contextualización}

En Colombia los cuerpos colegiados de elección popular (Congreso, asambleas departamentales, concejos y juntas administradoras locales) están conformados por un número determinado y plural de curules o sillas que son ocupadas por quienes representan al pueblo y que a su vez son los que toman decisiones y participan en los debates, a través de los cuales se busca lograr los fines del Estado social de derecho.

En lo que respecta a la Constitución Política de Colombia (2016), la Rama legislativa está integrada por el Congreso de la República, la que a su vez está compuesto por el Senado de la República (artículos 112 y 171), el cual consta de 102 curules, y por la Cámara de Representantes (artículos 112 y 176), integrada por 166 curules; por su parte, a nivel territorial los 32 departamentos cuentan con asambleas departamentales que según el artículo 299 están conformadas por no menos de 11 ni más de 31 miembros; además, en cuanto a los 1.101 municipios se refiere, los concejos municipales están formados de 7 a 21 miembros según lo dispone el artículo 312 y para los concejos distritales 45 miembros según el artículo 323; por último, las juntas administradoras locales están integradas de 3 a 9 miembros tal y como lo establece el artículo 119 de La Ley 136 de 1994 el cual fue modificado por la Ley 1551 de 2012 en su artículo 42 (Secretaría del Senado, 2016, p.3).

De ahí que con la reforma constitucional promulgada el día 1 de julio de 2015, consignada en el Acto Legislativo 02 de 2015, en cuyos artículos 1 y 4 se modificaron los artículos 112 y 134 de la Constitución Política de Colombia de 1991 (Secretaría del Senado, 2016); se tiene en el primer artículo la creación de nuevas curules para el Senado de la República y Cámara de Representantes y para las demás corporaciones públicas de elección popular se ordena una reserva especial de asignaciones sin alterar el número de curules actuales; seguidamente en el otro artículo especifica las faltas absolutas y temporales de ciudadanos elegidos popularmente indicando cuáles son materia de remplazo y cuáles no lo son y es en esta última la que genera la figura de la silla vacía para los cuerpos colegiados para congresistas, diputados, concejales municipales y distritales y miembros de las juntas administradoras locales. Cabe anotar que en cuanto al artículo 112 Superior se refiere, el legislador derivado amplió una curul para el Senado de la República y una para la Cámara de Representantes como un derecho personal de libre aceptación por el candidato elegido; de ahí que sobre este punto en particular aparece un estudio realizado en la Universidad Nacional de Colombia por su grupo de investigación de Partidos Políticos y Sistemas Electorales de la Facultad de Derecho, Ciencias Políticas y Sociales dirigido por David Alberto Roll Vélez y Juan Pablo Garnica Munévar, Isaac Morales Pérez y Andrés Leonardo Villamil Duarte en su artículo del proyecto de investigación "Análisis del comportamiento legislativo durante el trámite de la Reforma política de Equilibrio de Poderes" como resultado anotan: 
Respecto al segundo puesto en elecciones se propone una modificación al artículo 112 de la Constitución, la cual sugiere que la persona que quede en segundo lugar en la contienda presidencial, llegue al Senado de la República, el candidato de la vicepresidencia vaya a la Cámara, y que lo mismo suceda que cuando un candidato quede en segundo puesto en las elecciones en cualquier municipio de Colombia, vaya al concejo y , de igual manera cuando cada segundo candidato que aspiró a la gobernación, vaya a la asamblea, sin crear un solo puesto adicional en ningún cuerpo colegiado, este punto sirve como referente para probar que este tipo de propuestas tienen mayor apoyo, sin que este sea dependiente de la relación existente entre el gobierno y una bancada, en tanto que se le da mayor expectativa de participación a todos los actores políticos, así como mayor inclusión a los nuevos que surjan, generando un campo positivo sobre el sistema de partidos, a nivel particular, y un cambio en la participación sobre el sistema político, a nivel general. (Roll, et al, año 2014, pp.382).

De lo anterior se intuye que la motivación y participación política para participar en las contiendas electorales desde el 2018 en adelante, gozaran de mayor participación de partidos minoritarios y con mejores oportunidades de incluirse en los cuerpos colegiados a nivel territorial.

Ahora en cuanto al estudio de la figura de la silla vacía en su aplicación y consecuencia jurídica, suscita una problemática dentro del derecho, ya que en ciertos casos limita el nombramiento de remplazo que corresponde al siguiente de la lista electoral del partido al que pertenece en número de votos en el caso de listas abiertas o del siguiente en estricto orden descendente en listas cerradas.

En este orden de ideas, es importante aclarar que mientras la curul sea ocupada por el representante elegido, no existe ningún tipo de problema, pues esa es la finalidad; pero, si por el contrario, este representante no ocupa la curul, quedará vacante estructurándose una falta que puede ser temporal o absoluta y que en algunas circunstancias puede tener remplazo y en otras no; cuando esta última ocurre, la curul queda vacía generándose la figura de silla vacía como un castigo para el partido político a la que le fue asignada, de ahí que el legislador presentó el proyecto de acto legislativo N 010 de 2014 (Congreso de la República, 2014) mediante el cual justifica crear más restricciones personales a los candidatos y de igual manera a los partidos políticos, con el ánimo de dar un enfoque más actualizado a la Constitución Política de Colombia, creando herramientas que permitan al Estado precisar las calidades de sus dirigentes y restringir las luxaciones que en cierta medida, se le hacen a la responsabilidad política frente al pueblo elector; pero el legislador no contempló consideración alguna frente a la norma constitucional de restricción de derechos políticos estipulados en el artículo 23 de la Convención Interamericana de Derechos Humanos; disposición esta que es clara al determinar la restricción de los derechos políticos solo por sentencia penal debidamente ejecutoriada para el candidato; el referido artículo restringe y saca de la vida política de elección popular a los presuntos candidatos que se postulan en los diferentes cargos; la norma no castiga al pueblo elector sino al individuo como tal; es de anotar que los delitos contra la administración pública conllevan a una sentencia penal, concomitante con el artículo 23 de la Convención Interamericana de Derechos Humanos; pero lo que riñe con la norma es la aplicación de la figura de la silla vacía, ella decanta desde su inicio que es contraria a los derechos de representación popular generados por el sufragio popular. Ambas normas son legales en la legislación colombiana, pero que en su aplicación conllevan resultados contrarios al derecho de presentación popular. Ahora bien en cuanto a la aplicación de la figura de la silla vacía, se requiere de unas causales determinadas y específicas, establecidas por el constituyente derivado, así mismo se pretende con ello que los actuales representantes tengan una hoja de vida intachable y un perfil acorde con la investidura del cargo, con el propósito de que el pueblo se sienta confiado y bien representado por los titulares elegidos; en este orden de ideas, indica la Corte Constitucional de Colombia, una interpretación de la democracia participativa en la Sentencia T-066 de 2015 magistrada sustanciadora Gloria Stella Ortiz Delgado al indicar : 
En una democracia participativa, el ciudadano "está llamado a tomar parte en los procesos de toma de decisiones en asuntos públicos". Por lo tanto es indispensable que existan mecanismos adecuados para permitir que efectivamente la ciudadanía manifieste su opinión política, de tal modo que esta sea tenida en cuenta por las autoridades públicas. De lo contrato si no existen canales adecuados para que los ciudadanos puedan expresarse y garantizar la efectividad de su mandato, no será posible sostener el postulado democracia participativa, pues su capacidad para tener injerencia sobre el gobierno seguirá limitada únicamente a la faculta para depositar su voto para elegir a sus gobernantes. (parr.4, pt.6, lit.A, part. $3^{\circ}$ consideracione, Corte Constitucional , 2015).

Es de apreciarse que la voluntad del pueblo siempre se debe proteger para que el derecho de representatividad democrática surta efectos a nivel interno y externo como una determinación de libertad de los pueblos; por ello el sistema electoral cuenta con garantías constitucionales, vigilancia y controles legales que permiten el desarrollo de los actos democráticos mediante el sufragio general con el animo de garantizar el derecho fundamental de representatividad donde la observación de la elecciones se convierten en procesos electorales consustanciales (Nohlen, Zovatto, Orozco y Thompson, 1998) con el animo de que la comunidad internacional avale los actos de participación democrática que allí se realizan; por ello la excepción a este, es la aplicación de la silla vacía, para los cuerpos colegiados de elección popular en Colombia al crear una sanción al sufragante popular.

Nótese que la Constitución Política de Colombia de 1991 (2016), establece la organización política y consagra los principios rectores en la conformación del Estado; está dividida en dos partes, la primera, es dogmática la cual es la esencia inmodificable de su existencia, en la que se consagran los principios constitucionales, los fines del Estado, los derechos, deberes y libertades fundamentales de las personas, y la segunda parte es orgánica, en este sentido la Corte Constitucional en Sentencia T- 406 de 1992, magistrado ponente Ciro Angarita Barón, sienta postura al indicar que la Constitución está concebida de tal manera que la parte orgánica de la misma solo adquiere sentido y razón de ser como aplicación y puesta en obra de los principios y de los derechos inscritos en la parte dogmática de la misma (Corte,1992). En ese orden de ideas, la Constitución Política de Colombia está conformada en su totalidad por 380 artículos permanentes y 60 transitorios, adicionando los tratados y convenios internacionales ratificados por Colombia, los cuales conforman el bloque de constitucionalidad, mostrando con ello la amplitud de la actual Constitución, siendo uno de los principios fundamentales la norma de normas, tal y como aparece consagrado en el artículo 4 Superior (Secretaría del Senado, 2016, p.1), permitiendo la supremacía de la Constitución Política frente a la ley; así mismo, establece los derechos y deberes que la fundan y consagra las herramientas para su protección.

Tratándose de los derechos fundamentales, el artículo 40 Superior establece los denominados "derechos políticos" en virtud de los cuales toda "persona tiene derecho a participar en la conformación, ejercicio y control del poder político" (Secretaría del Senado, 2016, p. 2) y en los numerales del mismo se especifican los derechos a elegir y ser elegido y tomar parte en elecciones. Unido a ello, el artículo 99 de la Constitución Política de Colombia consagra la calidad de ciudadano frente al derecho al sufragio, el ser elegido y la ocupación de los cargos públicos, mientras que el artículo 100 de la Carta detalla una limitación del derecho al voto a los extranjeros (Secretaría del Senado, 2016, p. 3).

Asimismo, la Constitución (2016) establece en el capítulo 2 del título IV, el derecho a formar partidos políticos y afiliarse o retirarse de ellos y consagra los límites mínimos orientados al interés general. Por su parte el artículo 112 consagra el estatuto de la oposición, en cuyos incisos 4, 5 y 6 , incorporados por el artículo 1 del Acto Legislativo 02 de 2015, adiciona una curul para el senado y una para la Cámara de Representantes diferentes a las establecidas en los artículos 171 y 176 de la Carta, para que las asambleas departamentales y los concejos municipales o distritales destinarán una curul de las ya existentes, para 
suplir el derecho personal del candidato derrotado en gobernación y alcaldía; así mismo, se establece que la forma de asignarlas es mediante la regla general existente en el artículo 263 Superior, esto es, en orden descendente de acuerdo a la lista y con base a la cifra repartidora (Secretaría del Senado, 2016).

En cuanto a la declaración de los Derechos del Hombre y del Ciudadano; ella consta de 17 artículos dentro de los cuales se encuentran consagrados los derechos de igualdad, libertad y la organización del Estado, es de advertir que esta declaración por las posteriores discusiones y manifestaciones culminan en la declaración de los Derechos Humanos promulgada en el seno de las Naciones Unidas después de la segunda guerra Mundial; toda vez, que esta incluye los dos géneros (González, 1998, p.16).

En fecha de 16 de diciembre de 1966, la Asamblea General de las Naciones Unidas (ONU, 1966) en resolución 2200 A (XXI), elabora el Pacto Internacional de los Derechos Civiles y Políticos, que fue ratificado por la Ley 74 de 1968 y entró en vigor el 23 de marzo de 1976, respetando la libre determinación de los pueblos que lo han ratificado, consagra, una serie de principios que los Estados parte se comprometen a respetar y garantizar dentro de los cuales se encuentra en el artículo 25 como derecho y oportunidad a votar, elegir a sus representantes libremente y ser elegido en las respectivas elecciones, con el ánimo de participar en las funciones públicas (ONU, 2016).

Unido a ello, la Convención Americana sobre Derechos Humanos promulgada el 22 de noviembre de 1969 debidamente ratificada mediante la Ley 16 de 1972 (ONU, 2016), consagra en el artículo 23 los derechos políticos, mediante el cual permite al ciudadano participar en la dirección de asuntos públicos directamente o por representantes libremente elegidos, votar o ser elegido, tener acceso, en condiciones de igualdad a las funciones públicas del país.

Ambos tratados son claros en el sentido de determinar la inviolabilidad y sin restricción de los derechos políticos, salvo que así lo determine autoridad judicial, en proceso penal al haber sido hallado penalmente responsable.

En cuanto a derechos políticos como derechos humanos (Nohlen, Zovatto, Orozco, \& Thompson, 1998 $p$, 49) puede entenderse como un conjunto de atributos de la persona con el ánimo de participar democráticamente en un Estado. La participación entre ciudadano y Estado es estrecha, sometida la decisión de otro conglomerado de personas denominado pueblo, quienes motivan su intención a través de un voto mediante la acción de sufragar, con el animo de elegir a sus representantes, esto gira entorno a los derechos humanos de los pueblo libres que eligen su forma de mandato. La Genesis de la democracia gira entorno a la libertad de los pueblos y su modo de elegir a sus representantes donde la importancia radica en mayor participación popular mejor representatividad y legitimidad de los elegidos popularmente, bien sabiendo que lo que busca el pueblo es ser representados por personas dignas a quienes se les confía el poder. Dentro de la comparación del derecho democrático de América Latina, se ha desarrollado una sinergia utópica de justicia plasmada en la diferentes constituciones, pero que en realidad los resultados ha sido adversos para todos los países; toda vez que se ha visto suprimido las garantías individuales y han estallado dictaduras que han suprimido la democracias representativas que buscaban los pueblos libres, es por ello que hoy en día el sufragio adquiere condiciones muy especiales porque en ella han evolucionado intereses públicos que se desligan del pueblo.

La Silla Vacía en Colombia. Es importante anotar que por tanta "parapolítica y corrupción política" de los candidatos elegidos en elecciones populares en las dos últimas décadas, aparece en Colombia la figura de la silla vacía como un castigo a las organizaciones políticas al no tener el debido cuidado al momento de otorgar el aval a sus candidatos; de ello hace alusión la ley 1475 de 2011 en el artículo 12 ordinal $6^{\circ}$ (alcaldiabogotá.gov.co, 2013) se indica: 
Cuando se trate de condenas ejecutoriadas en Colombia o en el exterior por delitos relacionados con la vinculación a grupos armados ilegales y actividades del narcotráfico o de delitos contra los mecanismos de participación democrática o de lesa humanidad, el partido o movimiento que inscribió al condenado no podrá presentar candidato para la siguiente elección en la misma circunscripción. Si faltaren menos de 18 meses para la siguiente elección no podrá presentar terna, caso en el cual el nominador podrá libremente designar el remplazo (ord.6, art.12, L.1475, 2011)

Lo anterior es con el fin de preservar una hoja de vida intachable de los candidatos a las elecciones populares en los cuerpos colegiados y de que el pueblo se sienta bien representado; en ese orden de ideas ya con la promulgación de la Constitución Política el 04 de julio de 1991, la Asamblea Nacional Constituyente implanta en los artículos 134 y 261, la eliminación de la figura del remplazo o suplente, estableciendo que la curul vacante solamente podría ser ocupada en caso de faltas absolutas y la persona que la ocuparía sería el candidato no elegido de la misma lista en orden de inscripción sucesivo y decreciente; lo que quiere decir que en caso de las faltas temporales la figura de la silla vacía se aplicaba, en los órganos colegiados.

Igualmente, lo confirma la Corte Constitucional en Sentencia C - 532 de 1993 magistrado ponente Hernando Herrera Vergara, que sustenta en la ratio decidendi:

Los Senadores y Representantes a la Cámara elegidos legalmente no podrán ser reemplazados cuando quiera que en ellos se configure una falta de carácter temporal. La prohibición de la figura de los suplentes que consagró la Carta Fundamental, se refiere a los casos de faltas temporales de los Congresistas, cuando señala en su artículo 261 que ningún cargo de elección popular en corporaciones públicas tendrá suplente, lo que es distinto a los casos de falta absoluta en que la misma Constitución señaló las formas de suplir las vacancias que se presentan de manera definitiva (p.1).

Posterior a ello, el Acto Legislativo 03 del 15 de diciembre de 1993 modificó los artículos 134 y 261 de la Carta y con ello revive la figura del suplente para las faltas temporales y absolutas. En tal Virtud, el Congreso de la República expide la Ley 136 de 1994 donde en los artículos 51 y 52 se desarrolla lo preceptuado en la Constitución.

En el año de 2003, se intentó modificar nuevamente los artículos 134 y 261, mediante el referendo en la pregunta tercera, la que no fue aprobada por el pueblo.

Seguidamente, el Congreso de la República el 14 de julio de 2009 expide el Acto Legislativo 01 de 2009, que en sus artículos 6 y 10 modifica los artículos 134 y 261 de la Constitución Política de 1991, donde eliminó las suplencias nuevamente y estableció taxativamente los eventos en que podrían ser reemplazados los miembros de los cuerpos colegiados por las faltas absolutas y temporales, así mismo, consagró que por regla general en caso de falta temporal no dan lugar remplazo, y que existen faltas absolutas que no dan lugar a remplazo, apareciendo nuevamente la figura de la silla vacía. Dicha figura fue estudiada por la Corte Constitucional en sentencia C- 699 de 2013, magistrada ponente María Victoria Calle Correa.

En la actualidad se encuentra vigente el Acto Legislativo 02 del 01 de julio de 2015 el cual modifica el artículo 134 y elimina de la vida jurídica el artículo 261 de la Constitución Política de Colombia (2016), cuando consagra las faltas absolutas o temporales que dan y no dan lugar a remplazo. Igualmente se mantiene que los miembros de los cuerpos colegiados de elección popular no tienen suplentes, y se establece la figura de la silla vacía en los casos de faltas temporales o absolutas que no dan lugar a remplazo, dando como solución que el Consejo Nacional Electoral convoque a elecciones cuando el quórum se afecte en la mitad o menos y falten más de 24 meses para la terminación del periodo; en caso de cumplirse, quedará como está conformado. 
Al entrar a determinar y analizar la aplicación de las faltas temporales y absolutas contenidas en el caratular constitucional del artículo 134, se trae en primer lugar una tabla referencial mediante la cual se determinan unas características relacionadas con la pérdida de investidura frente a la silla vacía, ello permite conocer los puntos más relevantes que se desarrollan en el presente capitulo y en segundo lugar facilita diferenciar los márgenes jurídicos de aplicación en que la norma interviene.

Tabla 1. Tabla de relación

\begin{tabular}{|c|c|c|}
\hline Categorías & Pérdida de investidura & Silla vacía \\
\hline Tipo & General & Específica \\
\hline - A quiénes se les aplica & $\begin{array}{l}\text { Cuerpos colegiados de elección } \\
\text { popular } \\
\text { (Congreso de la República, } \\
\text { asambleas departamentales } \\
\text { concejos municipales y distritales y } \\
\text { juntas administradoras locales) }\end{array}$ & $\begin{array}{l}\text { Cuerpos Colegiados de Elección popular } \\
\text { (Congreso de la República, Asambleas } \\
\text { Departamentales Concejos Municipales y } \\
\text { Distritales y Juntas Administradoras Locales) }\end{array}$ \\
\hline -Circunstancia penal. & $\begin{array}{l}\text { Condena penal en firme y } \\
\text { debidamente ejecutoriada en } \\
\text { cualquier tiempo. }\end{array}$ & $\begin{array}{l}\text { Condena penal En firme y Debidamente } \\
\text { ejecutoriada, la orden de Captura, y medida } \\
\text { de aseguramiento privativa de la libertad y } \\
\text { vinculación formal en proceso penal, todos } \\
\text { ellos por delitos exclusivos contenidos en el } \\
\text { artículo } 134 \text { de la Constitución Política de } \\
\text { Colombia. }\end{array}$ \\
\hline $\begin{array}{l}\text { Autoridad competente para } \\
\text { decretarla }\end{array}$ & $\begin{array}{l}\text { Jurisdicción Contencioso } \\
\text { administrativa }\end{array}$ & Jurisdicción Ordinaria - Sala penal \\
\hline $\begin{array}{l}\text { Operador administrativo } \\
\text { competente para aplicar la } \\
\text { falta }\end{array}$ & $\begin{array}{l}\text { Presidente de la mesa directiva de } \\
\text { la Corporación del cuerpo } \\
\text { colegiado de elección popular }\end{array}$ & $\begin{array}{l}\text { Presidente de la mesa Directiva de la } \\
\text { Corporación del cuerpo colegiado de elección } \\
\text { popular }\end{array}$ \\
\hline El debido proceso & $\begin{array}{l}\text { Sí regulado- debidamente } \\
\text { estructurado }\end{array}$ & No. Por el contrario, es desproporcionado \\
\hline Equilibrio de fuerzas & Sí. & No. \\
\hline $\begin{array}{l}\text { Consecuencia a un } \\
\text { corporado }\end{array}$ & Sí. Aplica el remplazo & No. \\
\hline Producto jurídico. & $\begin{array}{l}\text { Cosa juzgada. Acto administrativo } \\
\text { de remplazo }\end{array}$ & $\begin{array}{l}\text { Cosa Juzgada y Acto Administrativo No al } \\
\text { Remplazo. }\end{array}$ \\
\hline Control político. & $\begin{array}{l}\text { Jurisdicción Contencioso } \\
\text { Administrativa, Justicia Ordinaria } \\
\text { Sala Penal, Procuraduría General } \\
\text { de la Nación, Consejo Nacional } \\
\text { Electoral, la tutela y Corte } \\
\text { Interamericana de Derechos } \\
\text { Humanos. }\end{array}$ & $\begin{array}{l}\text { Jurisdicción Contenciosa Administrativa, } \\
\text { Justicia Ordinaria Sala Penal, la tutela y Corte } \\
\text { Interamericana de Derechos Humanos. }\end{array}$ \\
\hline
\end{tabular}

Fuente: elaboración propia 
Como se aprecia en la anterior tabla, la pérdida de investidura frente a la figura de la silla vacía, es más garantista y más funcional dentro de la dinámica del debido proceso tanto para el candidato elegido por elección popular como para los electores.

La figura de la silla vacía aparece consagrada en la Constitución Política de Colombia de 1991 (Constitución política de 1991, 2011) en el artículo 134 que al tenor reza:

Artículo modificado por el artículo 4 del Acto Legislativo 02 de 2015. El nuevo texto es el siguiente: Los miembros de las Corporaciones Públicas de elección popular no tendrán suplentes. Solo podrán ser reemplazados en los casos de faltas absolutas o temporales que determine la ley, por los candidatos no elegidos que según el orden de inscripción o votación obtenida, le sigan en forma sucesiva y descendente en la misma lista electoral.

En ningún caso podrán ser reemplazados quienes sean condenados por delitos comunes relacionados con pertenencia, promoción o financiación a grupos armados ilegales o actividades de narcotráfico; dolosos contra la administración pública; contra los mecanismos de participación democrática, ni por Delitos de Lesa Humanidad. Tampoco quienes renuncien habiendo sido vinculados formalmente en Colombia a procesos penales por la comisión de tales delitos, ni las faltas temporales de aquellos contra quienes se profiera orden de captura dentro de los respectivos procesos.

Para efectos de conformación de quórum se tendrá como número de miembros la totalidad de los integrantes de la Corporación con excepción de aquellas curules que no puedan ser reemplazadas. La misma regla se aplicará en los eventos de impedimentos o recusaciones aceptadas.

Si por faltas absolutas que no den lugar a remplazo los miembros de cuerpos colegiados elegidos en una misma circunscripción electoral quedan reducidos a la mitad o menos, el Consejo Nacional Electoral convocará a elecciones para llenar las vacantes, siempre y cuando falten más de veinticuatro (24) meses para la terminación del periodo.

Parágrafo transitorio. Mientras el legislador regula el régimen de reemplazos, se aplicarán las siguientes reglas: i) Constituyen faltas absolutas que dan lugar a remplazo la muerte; la incapacidad física absoluta para el ejercicio del cargo; la declaración de nulidad de la elección; la renuncia justificada y aceptada por la respectiva corporación; la sanción disciplinaria consistente en destitución, y la pérdida de investidura; ii) Constituyen faltas temporales que dan lugar a remplazo, la licencia de maternidad y la medida de aseguramiento privativa de la libertad por delitos distintos a los mencionados en el presente artículo.

La prohibición de reemplazos se aplicará para las investigaciones judiciales que se iniciaron a partir de la vigencia del Acto Legislativo 01 de 2009, con excepción del relacionado con la comisión de delitos contra la administración pública que se aplicará para las investigaciones que se inicien a partir de la vigencia del presente Acto Legislativo (p.5).

El precitado artículo permite abstraer que existen dos tipos de faltas: las temporales y las absolutas, y a su vez, se detalla que para cada una de ellas se pueden aplicar dos fenómenos jurídicos, la que da lugar a remplazo y la que no da lugar a remplazo; así mismo, consagra las circunstancias o eventos para aplicar el remplazo o la figura de la "silla vacía", así: 
Tabla 2. Artículo 134 de la Constitución Política de Colombia (2016, p.5)

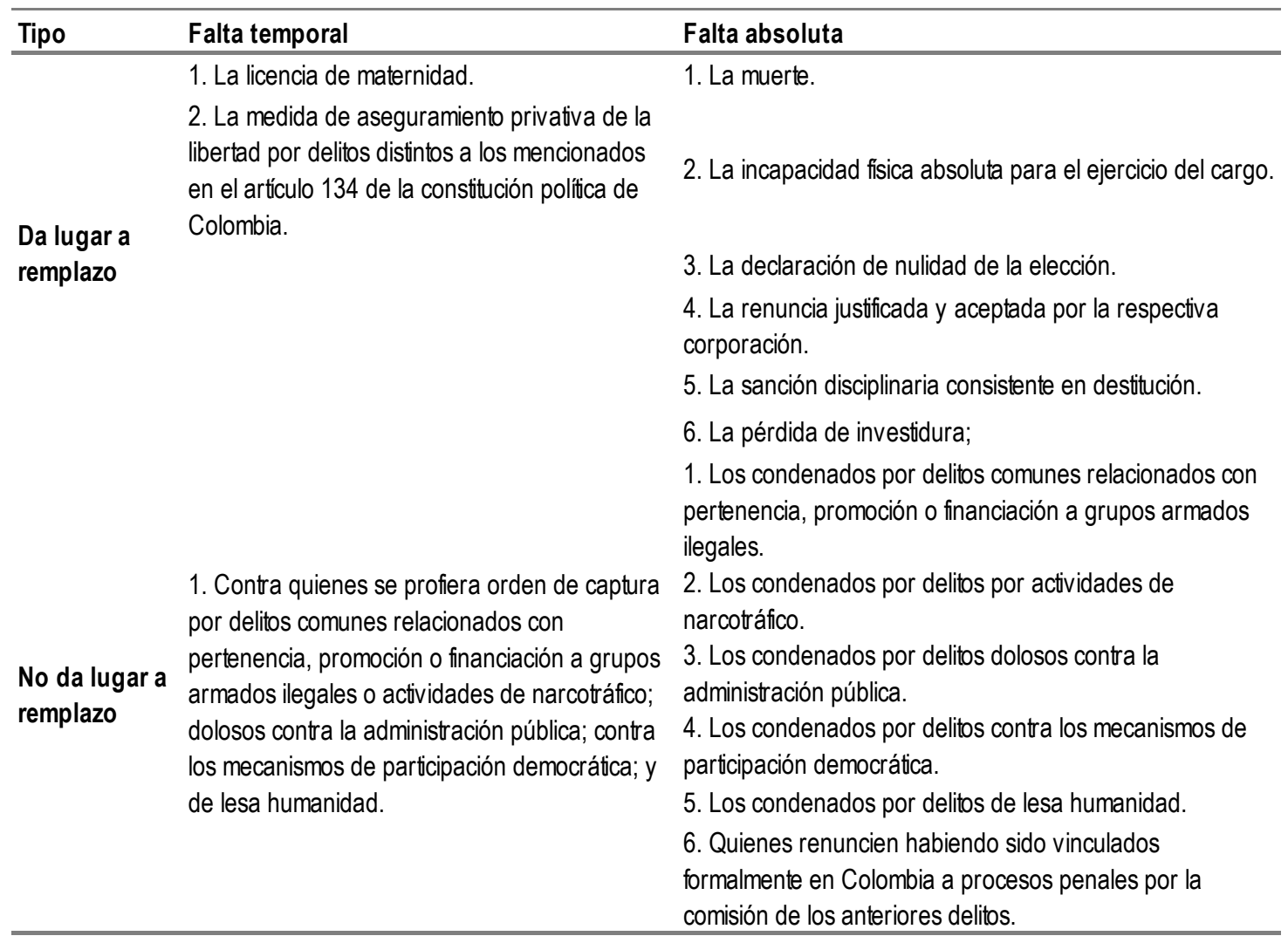

Fuente: elaboración propia.

Estas son las faltas temporales y absolutas que dan y no lugar a reemplazos según el artículo 134 Superior (Secretaría del Senado,2016), pero es necesario adentrarse aún más en la Carta para identificar las faltas mencionadas; además del artículo precitado, se hace necesario remitirse a los lineamientos constitucionales de los artículos 3, 6, 40, 103, 107,108, 112, 171, 176 y 263 de la de la Carta, en razón a que el Acto Legislativo 02 de 2015 modificó también los artículos 112 y 263 de la Constitución Política de 1991 (Secretaría del Senado, 2016) e introdujo una modificación hecha por el Congreso de la República, para los candidatos vencidos en las elecciones de la Presidencia y la Vicepresidencia, con el fin de garantizar el derecho de oposición, así mismo, a estas curules también se les puede dar aplicabilidad a la figura de la silla vacía, siempre y cuando alguno de ellos por decisión personal no quiera asumir su representación ante el Senado de la República o ante la Cámara de Representantes por tratarse de la fórmula presidencial electoral inscrita por el partido político, pero por el contrario si ambos deciden no ejercer su derecho de representación ante el Congreso de la República, según indica la norma, serán los que le sigan en su orden de asignación de conformidad lo disponga la lista de la autoridad electoral.

En tal sentido, el precitado acto legislativo expedido por el Congreso de la República, adiciona al artículo 112 de la Carta (Secretaría del Senado, 2016) tres incisos, los cuales se refieren a la creación adicional de una curul en el Senado de la República y una curul en la Cámara de Representantes diferentes a las ya 
existentes en los artículos 171 y 176 de la Constitución, y establece que las demás corporaciones quedan de la misma forma y se someten a las mismas reglas de las curules normales, solo con la diferencia que se respeta el derecho personal de oposición y la forma de asignación en caso de no aceptación de la curul. Así mismo el citado acto legislativo modifica en su totalidad el artículo 134 Superior, que establece las reglas de aplicación de la silla vacía.

\section{Aplicabilidad legal y jurisprudencial}

Una vez detallado el marco constitucional, se empiezan a determinar los aspectos legales yjurisprudenciales para cada situación especial que permita la aplicación o no de la silla vacía, en las faltas temporales o absolutas que dan lugar o no a remplazo, ante ello, se determina que:

Faltas temporales. Se detallan dos prototipos las que dan lugar a remplazo y las que no dan lugar a remplazo; a continuación, se identifica y se explica la aplicabilidad de cada una de ellas:

Faltas que dan lugar a remplazo en la curul:

La licencia de maternidad. Para dar aplicabilidad, el titular de la curul debe presentar ante la mesa directiva solicitud de licencia de maternidad, y por ostentar la calidad de servidor público al ser miembro de una corporación pública, tal como lo indica el artículo 123 de la Constitución Política de Colombia; esta corporación deberá ajustar la respuesta en las siguientes disposiciones.

La Ley 1468 de 2011 (Secretaría del Senado, 2016), la Circular externa conjunta 000013 del 12 de marzo de 2012 del Ministerio de Salud y Protección Social (Minsalud, 2016), el artículo 24 de la Ley 1551 de 2012, el parágrafo $2^{\circ}$ del artículo 29 de la Ley 617 de 2000 (Secretaría del Senado, 2016, p.1), el artículo 2 de la Ley 56 de 1993 (Secretaría del Senado, 2016, p.1), artículos 123 y 299 en su inciso $2^{\circ}$ de la Constitución Política de Colombia, (Secretaría del Senado, 2016) así mismo, las sentencias de la Corte Constitucional C-715 de 1998 del 25 de noviembre de 1998 Con Magistrado ponente Alfredo Beltrán Sierra, C-222 de 1999 del 14 de abril de 1999 con magistrado ponente José Gregorio Hernández Galindo, la C- 823 de 2006 del 04 de octubre de 2006 con magistrado ponente Jaime Córdoba Triviño y la C-174 de 2009 del 18 de marzo de 2009 con magistrado ponente Jorge Iván Palacio Palacio (Corte Constitucional, 2016); todas ellas ajustadas al artículo 207 de la Ley 100 de 1993 (Secretaría del Senado).

Con las anteriores disposiciones legales, se determina con claridad la calidad de servidores públicos que les asisten a los candidatos elegidos para los cuerpos colegiados de elección popular como titulares del derecho ante el silencio del legislador al no haber otorgado dicha calidad; seguidamente la licencia de maternidad tiene un periodo de catorce (14) semanas para la madre y de ocho (8) días hábiles para el padre. Ahora bien, la modalidad de la licencia de maternidad para la aplicación de la falta temporal que da lugar a remplazo procede por parto, adopción o por aborto.

Siendo importante anotar que en el eventual caso de fallecimiento de la madre (titular del derecho de la curul) que se encuentra gozando de la licencia de maternidad, la falta temporal sufre un cambio jurídico donde, una vez demostrado el deceso con el correspondiente Registro Civil de Defunción, la mesa directiva deberá proferir un nuevo acto administrativo decretando falta absoluta por muerte del titular que da lugar a remplazo, siendo ocupada por el siguiente de la lista por el mismo partido.

La medida de aseguramiento privativa de la libertad por delitos. Imputados, acusados o condenados, a todos los tipos penales existentes en el Código Penal pero se exceptúan los consagrados en el artículo 134 Superior (Secretaría del Senado, 2016, p.5), los cuales se enuncian más adelante. 
Para poder aplicarla se hace necesario que cuando se impute, acuse o condene a un servidor público perteneciente al cuerpo colegiado y se ordene su privación de libertad, ya sea en establecimiento carcelario o domiciliaria se procede a declarar la falta temporal que da lugar a remplazo del siguiente en la lista por el mismo partido mediante acto administrativo expedido por la mesa directiva de la corporación colegiada, el cual se tramitará en los términos del derecho de petición contenidos en los artículos 13 y siguientes del Código de Procedimiento Administrativo y Contencioso Administrativo, modificados por la Ley 1755 de 2015 (Secretaría del Senado, 2016, p.1).

En caso que se presente la muerte del titular de la curul en establecimiento penitenciario y/o carcelario o que este privado de su libertad en su domicilio por delitos distintos al artículo 134 de la Constitución Política de Colombia (Secretaría del Senado, 2016, p.5), una vez se demuestre con el respectivo Registro civil de defunción, la mesa directiva del cuerpo colegiado deberá expedir un nuevo acto administrativo modificando la falta temporal por falta absoluta que da lugar a remplazo al presentarse la muerte del titular de la curul.

Faltas que no dan lugar a remplazo para la curul. Presentándose la figura de "la silla vacía" para la curul cuando se presenten los delitos contemplados en el artículo 134 de la Carta y se dé por:

a)Orden de captura. Se presenta cuando la persona está ausente o se rehúsa a asistir a la investigación $o$ al proceso penal.

b) La medida de aseguramiento privativa de la libertad. Emitida por un juez de control de garantías a la persona que se vincula al proceso penal después de la imputación de cargos.

c) Vinculación formal. Se parte desde la audiencia de imputación de cargos, la persona asiste a todos los llamados que hace el fiscal en la investigación y/o dentro del proceso penal, pero no se le libró orden de captura ni se le profirió medida de aseguramiento.

La anterior connotación jurídica va estrechamente relacionada con los siguientes tipos de delitos tipificados en el Código Penal Colombiano:

d) Los de pertenencia, promoción o financiación a grupos armados ilegales o actividades de narcotráfico. Contenidos en el Código Penal Colombiano (2016, p.14) libro segundo título XII capítulos primero y segundo; y los del título XIII capítulo segundo, que son:

Artículo 340. Concierto para delinquir, artículo 341. Entrenamiento para actividades ilícitas, artículo 343. Terrorismo, artículo 345. Administración de recursos relacionados con actividades terroristas, artículo 346. Utilización ilegal de uniformes e insignias, artículo 347. Amenazas, artículo 348. Instigación a delinquir, artículo 349. Incitación a la comisión de delitos militares, artículo 357. Daño en obras o elementos de los servicios de comunicaciones, energía y combustibles, artículo 358. Tenencia, fabricación y tráfico de sustancias u objetos peligrosos, artículo 359. Empleo o lanzamiento de sustancias u objetos peligrosos, artículo 365. Fabricación, tráfico y porte de armas de fuego o municiones, artículo 366. Fabricación, tráfico y porte de armas y municiones de uso privativo de las fuerzas armadas, artículo 375. Conservación o financiación de plantaciones, artículo 376. Tráfico, fabricación o porte de estupefacientes, artículo 377. Destinación ilícita de muebles o inmuebles, artículo 377A. Uso, construcción, comercialización y/o tenencia de insumergibles o sumergibles, artículo 378. Estímulo al uso ilícito, artículo 379. Suministro o formulación ilegal, artículo 380. Suministro o formulación ilegal a deportistas, artículo 381. Suministro a menor, artículo 382. Tráfico de sustancias para procesamiento de narcóticos, Artículo 383. Porte de sustancias, y artículo 385. Existencia, construcción y utilización ilegal de pistas de aterrizaje. 
e) Los delitos contra la Administración Pública en modalidad dolosa. Contenidos en el Código Penal Colombiano (2016, p.16) del libro segundo título XV capítulos del primero al once del Código Penal Colombiano, que son:

Artículo 397 Peculado Por Apropiación, Artículo. 398 Peculado Por Uso, Artículo 399 Peculado Por Aplicación Oficial Diferente, Artículo 399-A Peculado por aplicación oficial diferente frente a los recursos de la seguridad social, Artículo 402 Omisión del Agente Retenedor o Recaudador, Artículo. 403 Destinos de recursos del tesoro para el estímulo o beneficio indebido de explotadores y comerciantes de metales preciosos, Artículo 403-A Fraude de subvenciones, Artículo 404. Concusión, Artículo 405 Cohecho Propio, Artículo 406 Cohecho Impropio, Artículo 407 Cohecho por dar u ofrecer, Artículo 408 Violación del régimen legal o constitucional de inhabilidades e incompatibilidades, Artículo 409 Interés indebido en la celebración de contratos, Artículo 410 Contrato sin cumplimiento de requisitos legales, Artículo 410-A. Acuerdos restrictivos de la competencia, Artículo 411 Tráfico de influencias de servidor público, Artículo 411-A Tráfico de influencias de particular, Artículo 412 Enriquecimiento ilícito, Artículo 413 Prevaricato por acción, Artículo 414 Prevaricato por omisión, Artículo 416 Abuso de autoridad por acto arbitrario e injusto, Artículo 417 Abuso de autoridad por omisión de denuncia, Artículo 418 Revelación de secreto, Artículo 419 Utilización de asunto sometido a secreto o reserva, Artículo 420 Utilización indebida de información oficial privilegiada, Artículo 421 Asesoramiento y otras actuaciones ilegales, Artículo 422 intervención en política, Artículo 423. Empleo ilegal de la fuerza pública, Artículo 424 Omisión de apoyo, Artículo 425 De la usurpación de funciones públicas, Artículo 426 Simulación de investidura o cargo,(p.17) Artículo 428 Abuso de la función pública, Artículo 429 Violencia contra Servidor Público, Artículo 429-A revelación de información de identidad de personas de inteligencia, Artículo 430 Perturbación de actos oficiales, Artículo 431 Utilización indebida de información obtenida en el ejercicio de función pública, Artículo 432 Utilización indebida de influencias derivadas del ejercicio de la función pública, Artículo 433 Soborno trasnacional, Artículo 434 Asociación para la comisión de un delito contra la administración pública (p.18)

f) Delitos contra los mecanismos de participación democrática. Contenidos en el libro segundo título XIV capítulo único del Código Penal Colombiano (2017, p.16) y son en su orden:

Artículo 386 Perturbación de certamen democrático, artículo 387 Constreñimiento al sufragante, artículo 388 Fraude al sufragante, artículo 389 Fraude en inscripción de cédulas, Artículo 389A Elección llícita de Candidatos, Artículo 390 Corrupción de sufragante, Artículo 390A Trafico de Votos, Artículo 391 Voto fraudulento, Artículo 392 Favorecimiento de voto fraudulento, Artículo 393 Mora en la entrega de documentos relacionados con una votación, Artículo 394 Alteración de resultados electorales, Artículo 395 Ocultamiento, retención y posesión ilícita de cédula, y Artículo 396 Denegación de inscripción, Artículo 396A Financiación de Campañas con Fuentes Prohibidas, 396B Violación de los Topes o límites de gastos en las campañas electorales y 396C Omisión de información del aportante.

g) Delitos de lesa humanidad (statute, 2002). Los que por integración normativa contenida en el artículo $2^{\circ}$ del Código Penal Colombiano (2016, p.1), y los contenidos y definidos en artículo 7 del Estatuto de Roma, que son: Asesinato, Exterminio, Tortura, Actos inhumanos, Esterilización forzada, Esclavitud, Encarcelación, Desaparición forzada, Deportación forzosa, Traslado o desplazamiento por la fuerza, Violación, Violencia sexual, Esclavitud sexual, Prostitución forzada, Embarazo forzado y Persecución.

Como se ha detallado, la aplicación de la figura de la silla vacía procede por faltas temporales que no dan lugar a remplazo contenidas en el artículo 134 Superior, en un total de noventa (90) tipos penales o delitos existentes en el Código Penal Colombiano. 
Para la aplicación jurídica de la figura de la silla vacía es necesario que se tenga plena certeza por parte de la mesa directiva del cuerpo colegiado de elección popular, que el servidor público se encuentre privado de la libertad por orden judicial $\mathrm{y} / \mathrm{o}$ vinculado a un proceso relacionado con los delitos enunciados 0 fuere condenado, momento en el cual la mesa directiva, garantizando el debido proceso, examinará los hechos y las pruebas, y mediante resolución debidamente motivada declarará la silla vacía de la curul temporalmente, al configurarse la vácate sin poder ser remplazo por el siguiente de la lista por prohibición directa del artículo 134 de la Constitución Política de Colombia (2016, p.5).

Situación jurídica de las faltas absolutas. Para este tipo de faltas se identifican dos clases:

a) Faltas que da lugar a remplazo en la curul. A continuación, se enumeran las faltas quedan lugar a remplazo en la curul:

1.La Muerte. En materia penal, el numeral 1 del artículo 82 del Código Penal Colombiano (2016) indica "Son causales de extinción de la acción penal: 1. La muerte del procesado." (p.3); igualmente, el Artículo 77. Del Código de Procedimiento Penal (2016) reza: "Extinción. La acción penal se extingue por muerte del imputado o acusado, prescripción, aplicación del principio de oportunidad, amnistía, oblación, caducidad de la querella, desistimiento, y en los demás casos contemplados por la ley" (p.2).

Teniendo en cuenta que el texto subrayado fue declarado exequible por la Corte Constitucional mediante Sentencia C-828 de 2010, en el entendido que el Juez de Conocimiento debe decidir oficiosamente o a petición del interesado, independientemente de que exista reserva judicial, poner a disposición u ordenar el traslado de todas las pruebas o elementos probatorios que se hayan recaudado hasta el momento en que se produzca la muerte, para que adelanten otros mecanismos judiciales o administrativos que permitan garantizar los derechos de las víctimas (Secretaría del Senado, 2016, p.2).

De los anteriores artículos citados, es menester decir que la muerte pone fin a la existencia de las personas, extingue los derechos y las acciones penales en cualquier instancia. Lo que indica que al momento de ocurrir el deceso del titular de la curul, ella sufre una alteración presentándose una vacancia absoluta que da lugar a llamar al siguiente de la lista por el mismo partido; siempre que se demuestre con el Registro civil de Defunción, de ahí que la mesa directiva a petición de parte deberá expedir un acto administrativo declarando la falta absoluta que da lugar a remplazo; de igual manera, solicitará mediante oficio dirigido al Consejo Nacional Electoral la Cancelación de la credencial del titular ya fallecido y la certificación del siguiente candidato de la lista por el mismo partido para notificarle que debe tomar posesión de la curul en el término de la distancia, so pena de incurrir en pérdida de investidura consagrada en la causal 7 del art. 296 de la Ley 5 de 1992 (Secretaría del Senado, 2016, p.8).

2. La incapacidad física absoluta para el ejercicio del cargo. Para la aplicación de este tipo de falta el cuerpo colegiado deberá prestar atención a los artículos 47 y 93 de la Constitución Política de Colombia (Secretaría del Senado, 2016, p.4), a la ley 361 de 1997 (Secretaría del Senado, 2016), a la Ley 762 de 2002 (Secretaría del Senado, 2016), el Decreto 1538 del 17 mayo de 2005 (Alcaldía Bogotá, 2016), la Sentencia C-458 del 22 de julio de 2015 de la Corte Constitucional, con magistrada ponente Gloria Stella Ortiz Delgado; que considera lo siguiente:

29. Teniendo en cuenta la noción de bloque de constitucionalidad, es importante mencionar algunas normas internacionales sobre los derechos de las personas en situación de discapacidad que han sido referidas por la jurisprudencia de esta Corte. Varios instrumentos son parte del softlaw, sin embargo, resultan relevantes por demostrar las tendencias del Derecho Internacional sobre la especial protección y búsqueda de efectividad de los derechos de las personas en situación de discapacidad, además son un parámetro interpretativo para los Estados. Con todo, el contenido y la naturaleza de las medidas concretas que el Estado debe adoptar, 
es objeto de discusión en el ámbito del Derecho Internacional de los derechos humanos (DIDH), debido a la vulnerabilidad de este grupo poblacional y el tipo de discriminación que la afecta, ligada a la posición social frente a su situación. En efecto, las personas en situación de discapacidad han tenido que enfrentar a distintas barreras que les han impedido el goce efectivo de sus derechos. Se han presentado obstáculos culturales -que perpetúan los prejuicios-, físicos -que limitan la movilidad, la integración social y la efectiva participación comunitaria-, y legales -que impiden los avances normativos en distintas materias. (p.1)

En lo anterior se aprecia claramente una protección especial las personas con discapacidad física y para continuar con esa garantía de derechos constitucionales, y es pertinente anotar, que la mesa directiva del cuerpo colegiado de elección popular al dar aplicación a este tipo de falta absoluta que da lugar a remplazo, deberá tener en cuenta que la persona titular del Derecho de la curul se encuentre en "estado de coma" o "enajenación mental total" debidamente demostrada y declarada, dado que las demás condiciones están ya protegidas.

3. La declaración de nulidad de la elección. Es competencia de la jurisdicción Contencioso Administrativo dentro del término de treinta días (30), en aplicación a los artículos 139, numeral 6 del artículo 161, el literal a del numeral 2 del artículo 164 y el numeral 5 del artículo 275 del Código de Procedimiento Administrativo y Contencioso Administrativo (CPACA, 2016, p.7).

Razones por las cuales en la aplicación de esta falta el cuerpo colegiado debe recibir notificación del órgano judicial de cierre indicando la ejecución de la sentencia de Nulidad Electoral y los efectos jurídicos de dicha decisión como lo disponen los artículos 275, 287, 288 y 289 del CPACA (2016, p.7), los que deben estar armonizados con el artículo 134 de la Constitución Política de Colombia (2016, p.5).

Las causales de nulidad electoral son las contenidas en el artículo 275 del Código de Procedimiento Administrativo y de lo Contencioso Administrativo (2016).; de igual manera, las prohibiciones de los artículos 126, 127, 128, 129, 136, 172, 177, 179, 180, 181,182, 299 y 312 de la Constitución Política de Colombia (Secretaría del Senado, 2016) se demandan por nulidad electoral dentro del término de treinta días (30) cuando un servidor público de un cuerpo colegiado de elección popular incurra en alguna de ellas; se tendrán en cuenta las causales de inhabilidad e incompatibilidad contenidas en los artículos 2, 3, 4 y 44 en la Ley 1474 de 2011.

Es importante anotar que la falta absoluta a que alude el artículo 312 de la Constitución Política de Colombia (Secretaría del Senado, 2016) no está contenida en el artículo 134 Superior, por ello hace que esta falta a pesar de estar plasmada directamente en la constitución, ella no da lugar a remplazo en forma directa, sino indirecta siendo menester demandar por nulidad electoral, si se está dentro de los términos anotados o por pérdida de investidura por causal de vulneración al régimen de inhabilidades e incompatibilidades.

Ahora en cuanto a incompatibilidades e inhabilidades contenidas en los artículos 33, 34, 40 , 41 y 44 de la Ley 617 de 2000 (2016) de los servidores públicos señalados en el artículo 126 de la Constitución Política de Colombia (2016) se demandan por nulidad electoral cuando incurre en esta causal el miembro del cuerpo colegiado de elección popular.

De igual forma, ocurre con las inhabilidades contenidas en los artículos 43 de la Ley 136 de 1994 modificado por la Ley 617 de 2000 en su artículo 40. (Secretaría del Senado, 2016).

Se indica que la prohibición contenida en el artículo 44 de la Ley 136 de 1994 (Secretaría del Senado, 2016), también se demanda por nulidad electoral. 
Que frente al cuerpo colegiado de elección popular para las juntas administradoras locales en la aplicación de la falta absoluta por nulidad de la elección electoral, se le aplica todo el régimen de inhabilidades e incompatibilidades de los congresistas, diputados y concejales de las normatividades citadas, además de ello las prohibiciones del artículo 130 de la Ley 136 de 1994 (Secretaría del Senado, 2016).

Que frente a las incompatibilidades consagradas en el artículo 45 de la Ley 136 de 1994 (2016), se tendrá en cuento lo siguiente:

1. Aceptar o desempeñar cargo alguno en la administración pública, ni vincularse como trabajador oficial o contratista, so pena de perder la investidura. Modificado por el artículo 3 de la Ley 177 de 1994. Declarado EXEQUIBLE por Sentencia C 194 de 1995, Sentencia C 231 de 1995, Sentencia C 232 de 1995, todos de la Corte Constitucional.

2. Ser apoderado ante las entidades públicas del respectivo municipio o ante las personas que administren tributos procedentes del mismo, o celebrar con ellas, por sí o por interpuesta persona, contrato alguno, con las excepciones que más adelante se establecen.

3. Ser miembros de juntas o consejos directivos de los sectores central o descentralizado del respectivo municipio, o de instituciones que administren tributos procedentes del mismo.

4. Celebrar contratos o realizar gestiones con personas naturales o jurídicas de derecho privado que administren, manejen o inviertan fondos públicos procedentes del respectivo municipio o sean contratistas del mismo o reciban donaciones de éste. Radicación 751 de 1995 Sala de Consulta y Servicio Civil.

5. Adicionado por el artículo 41 de la Ley 617 de 2000. (p.1)

4. La renuncia justificada y aceptada por la respectiva corporación. En cuanto a este tipo de falta absoluta para los Congresistas, es decir, Senadores y Representantes a la Cámara, dicha renuncia debe ser presentada ante la respectiva corporación legislativa y en caso de receso debe ser presentada ante la mesa directiva; quienes deben pronunciarse en el término de (10) días siguientes contemplado en el artículo 275 de la Ley 5 de 1992 (Secretaría del Senado, 2016, p.8).

Ahora bien, en el caso de los diputados, la presentación de la renuncia se hará ante el presidente de la asamblea departamental quien nombrará al siguiente diputado de la misma lista electoral como lo dispone el artículo 38 del Decreto 1222 de 1986 (Alcaldía de Bogotá, 2016, p.1) y artículo 134 de la Constitución Política de Colombia (Secretaría del Senado, 2016, p.5).

En caso de receso de la Asamblea Departamental, se aplicará lo dispuesto en el artículo 39 del Decreto 1222 de 1986 (Alcaldía de Bogotá, 2016) mediante el cual, el diputado deberá presentar la renuncia al gobernador para que éste decida y llame al siguiente de la lista según lo ordenado en el artículo 134 de la Constitución Política de Colombia (Secretaría del Senado, 2016).

En cuanto al Concejo Municipal, se presentan dos modalidades, así: la primera, es cuando el concejo municipal está en sesiones, ya sean ordinarias o extraordinarias, el titular de la curul debe presentar la renuncia al presidente del cuerpo colegiado, manifestando su voluntad de hacer dejación de su investidura como concejal, determinando la fecha a partir de la cual se quiere hacer. La segunda, si es el presidente del concejo municipal o distrital es quien presenta su renuncia, éste lo debe hacer en las mismas condiciones anteriormente anotadas, pero a diferencia de ser presentada a la mesa directiva, obrando de conformidad con el artículo 53 de la ley 136 de 1994 (Secretaría del Senado, 2016). 
En el caso que el Concejo Municipal no esté sesionando, la renuncia deberá ser presentada en las condiciones del literal A), numeral 8 del artículo 91 de la ley 136 de 1994, la que fue modificada por la Ley 1551 de 2012 en su artículo 29 y la sentencia de constitucionalidad C-647 de 2002 de la Corte Constitucional magistrado ponente Álvaro Tafur Galvis (Secretaría del Senado, 2016, p.2); en tal caso el trámite de la renuncia cambia, habida cuenta que el concejal, titular del Derecho presentará la renuncia ante el alcalde municipal y este expedirá un decreto indicando la manifestación voluntaria del concejal de renunciar a su investidura y curul, señalando la fecha en que se dará inicio y el remplazo del siguiente en la lista tal como lo indica el artículo 134 de la Constitución Política de Colombia (Secretaría del Senado, 2016) por tratarse de funciones específicas del alcalde municipal.

Por último, en cuanto a las juntas administradoras locales, para la aplicación de falta absoluta por renuncia que da lugar a remplazo por el siguiente de la lista, se procederá presentando la renuncia a la mesa directiva, la cual dará aplicación a lo establecido en el artículo 129 de la Ley 136 de 1994 (Secretaría del Senado, 2016), según el cual:

Artículo 129. Reemplazos. Los miembros de las Juntas Administradoras Locales no tendrán suplentes y sus faltas absolutas serán llenadas por los candidatos no elegidos, según el orden de inscripción en la lista correspondiente.

Constituyen faltas absolutas de los miembros de las juntas administradoras locales, su muerte, su renuncia aceptada, la declaratoria de nulidad de la elección y la decisión de autoridad competente que los prive del derecho a ejercer funciones públicas (p.2).

5. La sanción disciplinaria consistente en destitución. Están contenidas en el Código Único Disciplinario, los del estatuto anticorrupción, el Decreto 126 de 2010 (Alcaldía de Bogotá, 2016) y Ley 1523 de 2012 (Secretaría del Senado, 2016); para la aplicación de esta falta absoluta que da lugar a remplazo por el siguiente de la lista por el mismo partido, es necesario indicar que como ente disciplinador y competencia sancionatoria está en cabeza de la Procuraduría General de la Nación para los miembros de la corporaciones públicas, el fallo debe estar ejecutoriado y en firme; seguidamente, se notificará al cuerpo colegiado de elección popular, para que ellos den aplicación al artículo 134 de la Constitución Política de Colombia (Secretaría del Senado, 2016), es de anotar que lo anterior es independiente del control de legalidad que se puede ejercer ante la Jurisdicción Contenciosa Administrativa como lo indica el numeral 8 del art. 156 del Código de Procedimiento Administrativo y de los Contencioso Administrativo (Secretaría del Senado, 2016, p.4).

6. La pérdida de investidura. Para los cuerpos colegiados de elección popular se tiene que en sentencia C-254A del veintinueve (29) de marzo de 2012, la Corte Constitucional con ponencia del Magistrado Jorge Ignacio Pretelt Chaljub (Corte Constitucional, 2012), resolvió la demanda de inconstitucionalidad en contra del Artículo $1^{\circ}$ de la ley 144 de 1994 sobre el procedimiento de pérdida de investidura de los congresistas; para ello, la Corte retoma las consideraciones de carácter punitivo disciplinario del Consejo de Estado, mediante el cual define el concepto de pérdida de investidura de la siguiente manera:

La pérdida de investidura es una sanción de carácter disciplinario de características especiales que la distinguen de otros regímenes de responsabilidad de los servidores públicos, así como también, de los procesos penales, electorales, de responsabilidad fiscal, e incluso del proceso disciplinario realizado por la administración pública. En este sentido, esta Corporación ha señalado en reiterada jurisprudencia la especial naturaleza de esta acción: Sobre la naturaleza de esta figura la jurisprudencia constitucional ha señalado que se trata de "un verdadero juicio de responsabilidad política que culmina con la imposición de una sanción de carácter jurisdiccional, de tipo disciplinario” por la transgresión del estricto código 
de conducta previsto para los miembros de las corporaciones representativas. Consiste por lo tanto en un proceso jurisdiccional, de carácter sancionatorio, el cual culmina -en el caso que se comprueba la transgresión de una de las causales legalmente previstas- con la imposición de una sanción que constituye una sanción equiparable, por sus efectos y gravedad, a la destitución de los altos funcionarios públicos.

Similar postura tiene el Consejo de Estado, el cual también ha resaltado el carácter punitivo disciplinario especial de la pérdida de investidura: Como se ha dicho en varias ocasiones, la acción de pérdida de investidura es una acción de tipo punitivo, especial, de carácter disciplinario que tiene por objeto general el de favorecer la legitimidad del Congreso de la República mediante la finalidad específica de sancionar conductas contrarias a la transparencia, a la probidad y a la imparcialidad en que pudieran en un momento dado incurrir los congresistas.

Conocida la posición conceptual que adoptan la Corte Constitucional y el Consejo de Estado sobre la pérdida de investidura, es importante añadir la doctrina del Doctor Frenando Brito Ruiz (2011) según la cual:

Tampoco se puede perder de vista la magnitud de la sanción que se impone, lo cual significa que el congresista que pierde su investidura no puede volver hacer elegido para el Congreso, posteriormente, en ninguna época, lo que la hace una sanción intemporal permanente, con la que pierde además una parte importante del primer derecho político fundamental, por el cual entra a formar parte de los órganos de representación política, y en consecuencia queda privado del derecho a ser elegido (p.26).

De lo anterior se desprende que los efectos de una sentencia judicial que decreta la pérdida de investidura permite apartar de la contienda política nacional al titular de la curul del cuerpo colegiado de elección popular en forma definitiva.

De ahí que para la imposición de esta falta absoluta que da lugar a reemplazos por el siguiente en la lista del mismo partido político, tal como lo indica el artículo 134 de la Constitución Política de Colombia (Secretaría del Senado, 2016, p.5), la Ley 144 de 1994 (Secretaría del Senado, 2016) en su artículo $1^{\circ}$ provee que para los congresistas el fallo será en única instancia ante el Consejo de Estado por solicitud presentada por la mesa directiva de la Cámara o de cualquier ciudadano según el artículo 143 del Código de Procedimiento Administrativo y de lo Contencioso Administrativo (2016, p.4); de tal manera que para congresistas las causales de pérdida de investidura son las contenidas en el artículo 183 de la Constitución Política de Colombia (Secretaría del Senado, 2016), también se deben considerar las otras causales indicadas en el artículo 109 de la Carta (2016, p.4), como es superar los topes de financiación de las campañas políticas; de igual manera, el artículo 110 de la Carta (2016) al indicar "por contribuir a partidos o movimientos políticos" (p.4); adicionalmente se tiene como causales las contendidas en los artículos 41, 270 274, 286, 287, 288, 289, 290, 91,292 293, 294, 295, 296, 299 de la Ley 5 de 1992 (Secretaría del Senado, 2016); de igual manera, también para los demás corporados la aplicación de las causales establecidas por el artículo 48 de la Ley 617 de 2000 (Secretaría del Senado, 2016).

Teniendo en cuenta lo anterior, la jurisprudencia del Consejo de Estado Sala de lo Contencioso Administrativo, Sección Primera, dos (2) de junio de dos mil dieciséis (2016), consejero ponente: Roberto Augusto Serrato Valdés, hace referencia respecto de la Pérdida de Investidura por no tomar posesión del cargo dentro de los tres días siguientes a la instalación del Concejo, procede la sala a decidir el recurso de apelación interpuesto oportunamente por la parte demandada, en contra de la sentencia proferida por la Sala Plena del Tribunal Administrativo del Cauca, el veintisiete (27) de noviembre de dos mil quince (2015), mediante la cual se decretó la pérdida de la investidura que ostentaba la señora Karol Adriana Guerrero Isaza, como concejal del municipio de Rosas (Cauca), para el período 2012-2015; en razón a que: 
La falta de requisitos para obtener título de abogado no constituye fuerza mayor que excuse al candidato de tomar posesión. Se estudia caso de candidato electo que se excusa de tomar posesión como concejal argumentando la existencia de una incompatibilidad entre el ejercicio del cargo para el cual fue electo y la práctica que debe realizar para obtener el título de abogado. según el análisis jurisprudencial del numeral $3^{\circ}$ del artículo 48 de la Ley 617 del 2000, el cual establece la pérdida de investidura para los concejales cuando no tomen posesión dentro de los tres días siguientes a la fecha de instalación de las asambleas o concejos, se concluye que tal circunstancia no puede constituir un evento de fuerza mayor que inhiba al ciudadano electo para tomar la respectiva posesión, toda vez que la fuerza mayor, en estos casos, se produce cuando el hecho exógeno al concejal elegido es imprevisible e irresistible y se traduce en la imposibilidad absoluta de dar cumplimiento a la obligación mencionada. Así las cosas, se aclara que resulta previsible que en el desarrollo de la carrera universitaria se debían cumplir los requisitos para la obtención del título dentro de los que se encuentra la realización de la práctica jurídica, "por lo que es posible haber planeado el cumplimiento de este requisito de manera que no se afectara el ejercicio de la investidura para la cual fue elegido.

En otro caso, el Consejo de Estado al estudiar el caso de un concejal que manifestó su deseo de no posesionarse, lo cual fue interpretado como una renuncia, hizo unas consideraciones sobre la improcedencia de emitir una renuncia si no se ha producido la posesión a un cargo. Así señaló en la Sentencia de 6 de agosto de 2015, sección primera, magistrada ponente María Elizabeth García González, Exp. 41001233300020130033701 (Relatoría Consejo de Estado, 2015):

Sobre la renuncia también se debe precisar que ella no se puede producir por cualquier motivo, sino que debe existir una justa causa, tal como se consagró desde el Acto Legislativo 01 de 2009, que modificó el artículo 134 de la Carta Política, hoy modificado por el Acto Legislativo 02 de 2015, pues lo que en últimas se busca evitar es el llamado "carrusel de reemplazos" por el cual, el elegido simplemente renuncia y a raíz de la suplencia, puede terminar ocupando el cargo hasta el último de una lista, menoscabando las bases de la democracia, al defraudar la voluntad popular, debilitada por esa vía en la que incluso un candidato con votación menor puede terminar ocupando la curul. Así las cosas, se imponía a la doctora Guerrero Isaza exhibir unos motivos con suficiente peso, para dar lugar al remplazo en su curul, lo cual no se dio.

Es por ello que, una vez comprobado y declarado que el servidor público del cuerpo colegiado se encuentra incurso en una causal de Muerte, incapacidad física absoluta para el ejercicio del cargo, declaración de nulidad de la elección, renuncia justificada y aceptada por la respectiva corporación, sanción disciplinaria consistente en destitución y/o pérdida de investidura, esta corporación, a través de la mesa directiva deberá ajustarla con una de las causales, y declarar la vacante de la curul dando aplicación al primer inciso del artículo 134 de la Constitución Política, llamando al siguiente de la lista del partido para ocuparla.

b) Faltas que no dan lugar a remplazo para la curul. Presentándose la figura de la silla vacía para la curul teniendo en cuenta la prohibición del artículo 134 Superior (Secretaría del Senado, 2016, p.5) en los noventa (90) tipos penales descritos, y además deben estar con condena debidamente ejecutoriada, solo en los siguientes casos:

1 En delitos de pertenencia, promoción o financiación a grupos armados ilegales. Condena penal u orden de captura expedida por el Juez Penal de Conocimiento o del Juez de Ejecución de Penas y Medidas de Seguridad.

2 En delitos relacionados con actividades de narcotráfico. Condena penal u orden de captura expedida por el Juez Penal de Conocimiento o del Juez de Ejecución de Penas y Medidas de Seguridad. 
3 En delitos dolosos contra la administración pública. Condena penal u orden de captura expedida por el Juez Penal de Conocimiento o del Juez de Ejecución de Penas y Medidas de Seguridad.

4 En delitos contra los mecanismos de participación democrática. Condena penal u orden de captura expedida por Juez Penal de Conocimiento o del Juez de Ejecución de Penas y Medidas de Seguridad.

5 En delitos de lesa humanidad. Condena penal u orden de captura expedida por el Juez Penal de Conocimiento o del Juez de Ejecución de Penas y Medidas de Seguridad.

6 En renuncia habiendo sido vinculado formalmente en Colombia a procesos penales. Por la comisión de los delitos mencionados.

secuencia jurídica en la aplicación de la figura de la silla vacía en aquellos casos de falta temporal o absoluta en los cuerpos colegiados de elección popular en Colombia

1. Por la entidad que decreta la falta. En el caso que nos ocupa la competencia gira en cuatro estadios así:

1.1 Por la presidencia del senado de la República, de la presidencia de la Cámara de Representantes, de la presidencia del Congreso en Pleno, de la asamblea departamental, de la presidencia del concejo municipal o de la Junta Administradora Local. Conocen de las siguientes faltas ya sean temporales, permanentes o absolutas para decretar la figura jurídica de la silla vacía a petición de parte o de oficio en asuntos relacionados a continuación:

1.1.1 Por muerte. Genera una falta absoluta que da lugar a remplazo del siguiente en la lista por el mismo partido.

1.1.2 Por incapacidad física absoluta para el ejercicio del cargo. Genera una falta absoluta que da lugar a remplazo del siguiente en la lista por el mismo partido.

1.1.3 Por renuncia justificada y aceptada por la respectiva corporación. Genera una falta absoluta que da lugar a remplazo del siguiente en la lista por el mismo partido.

1.1.4 Por Fallo judicial de Pérdida de Investidura debidamente ejecutoriado y en firme genera una falta absoluta que da lugar a remplazo del siguiente en la lista por el mismo partido.

1.1.5 Por fallo de sanción disciplinaria consistente en destitución debidamente ejecutoriado y en firme genera una falta absoluta que da lugar a remplazo del siguiente en la lista por el mismo partido.

1.1.6 Presentación de orden de captura por delitos comunes relacionados con pertenencia, promoción o financiación a grupos armados ilegales o actividades de narcotráfico; dolosos contra la administración pública; contra los mecanismos de participación democrática o por Delitos de Lesa Humanidad. Debidamente emitida de autoridad competente y que este vigente genera una falta temporal permanente que no da lugar a remplazo se presenta la figura de la silla vacía para la curul. Así mismo, hay que tener en cuenta que la orden de captura por delitos distintos a los mencionados en el artículo 134 Superior constituyen una falta temporal que da lugar a remplazo del siguiente en la lista por el mismo partido.

1.1.7 Con la presentación de la sentencia debidamente ejecutoriada y en firme la condena por delitos comunes relacionados con pertenencia, promoción o financiación a grupos armados ilegales o actividades de narcotráfico; dolosos contra la administración pública; contra los mecanismos de participación democrática o por Delitos de Lesa Humanidad: Genera una falta absoluta que no da lugar a remplazo, 
se presenta la figura de la silla vacía para la curul. Teniendo en cuenta que la Condena Penal que se dé por delitos distintos a los mencionados en el artículo 134 constituyen una falta temporal que da lugar a remplazo del siguiente en la lista por el mismo partido.

1.1.8 La solicitud presentada por licencia de maternidad. Genera una falta temporal que da lugar a remplazo del siguiente en la lista por el mismo partido solo por el tiempo que dure la licencia.

1.1.9 Por medida de aseguramiento privativa de la libertad por delitos distintos a los mencionados en el artículo 134 de la Constitución Política de Colombia (2016, p.5): Genera una falta temporal que da lugar a remplazo del siguiente en la lista por el mismo partido; este tipo de falta está sujetos a cambios de reintegro a la curul si el elegido es absuelto de todos los cargos, regresa a su curul aun cuando el fallo de primera instancia haya sido apelado por la fiscalía o por el ministerio público o por la víctima. 0 bien puede transformarse en falta absoluta que da lugar a remplazo si este fenómeno ocurre cuando el elegido se encuentra privado de su libertad y ocurre el fenómeno de la muerte. Ocurrido tal hecho el presidente del cuerpo colegiado debe expedir un nuevo acto administrativo modificando le remplazo de falta temporal a falta absoluta por ocurrir el fenómeno de la muerte del titular reemplazado.

2 Factor competencia del Contencioso Administrativo. Conocen de las siguientes faltas ya sean temporales, permanentes o absolutas para decretar la figura jurídica de la silla vacía a petición de parte o de oficio en:

2.1 Pérdida de investidura. Por violación a los topes máximos de financiación de la campaña política prevista en el inciso 7 del artículo 109 de la Constitución Política de Colombia (Secretaría del Senado, 2016, p.4); por violación del régimen de inhabilidades e incompatibilidades, o del régimen de conflicto de intereses contemplado en el numeral $1^{\circ}$ del artículo 183 de la Constitución Política de Colombia (2016, p.6); por la inasistencia, en un mismo período de sesiones, a seis reuniones plenarias en las que se voten proyectos de acto legislativo, de ley o mociones de censura del numeral $2^{\circ}$ del artículo 183 de la Constitución Política de Colombia (2016, p.6); por no tomar posesión del cargo dentro de los ocho días siguientes a la fecha de instalación de las Cámaras, o a la fecha en que fueren llamados a posesionarse del numeral $3^{\circ}$ del artículo 183 de la Constitución Política de Colombia (2016, p.6); por indebida destinación de dineros públicos del numeral $4^{\circ}$ del artículo 183 de la Constitución Política de Colombia (2016, p.6) y el numeral $4^{\circ}$ del artículo 48 de la Ley 617 de 2000 (Secretaría del Senado, 2016, p.2); por tráfico de influencias debidamente comprobado del numeral $5^{\circ}$ del artículo 183 de la Constitución Política de Colombia (2016, p.6) y numeral $5^{\circ}$ del artículo 48 de la Ley 617 de 2000 (Secretaría del Senado, 2016, p.2); por violación del régimen de incompatibilidades o del de conflicto de intereses del numeral $1^{\circ}$ del artículo 48 de la Ley 617 de 2000 (Secretaría del Senado, 2016, p.2); por la inasistencia en un mismo período de sesiones a cinco (5) reuniones plenarias o de comisión en las que se voten proyectos de ordenanza o acuerdo, según el caso del numeral $2^{\circ}$ del artículo 48 de la Ley 617 de 2000 (Secretaría del Senado, 2016, p.2); por no tomar posesión del cargo dentro de los tres (3) días siguientes a la fecha de instalación de las asambleas o concejos, según el caso, o a la fecha en que fueren llamados a posesionarse del numeral $3^{\circ}$ del artículo 48 de la Ley 617 de 2000 (Secretaría del Senado, 2016, p.2) y por último, por las demás causales expresamente previstas en la ley del numeral $6^{\circ}$ del artículo 48 de la Ley 617 de 2000 (Secretaría del Senado, 2016, p.2).

2.2 Por la declaración de nulidad de la elección contemplada en el artículo 139 del Código de Procedimiento Administrativo y de lo Contencioso Administrativo (Secretaría del Senado, 2016, p.4).

3 El factor competencia del Consejo Nacional Electoral. La facultad del Consejo Nacional Electoral se encuentra suspendida hasta que el Congreso de la República expida la ley estatutaria que regule la revocatoria de inscripción de candidatos por violación al régimen de inhabilidades o por doble militancia; 
entre tanto corresponde a la jurisdicción contenciosa asumir esta competencia del Consejo de Estado, sentencia №11001-03-28-000-2011-00068-00 del 6 de mayo de 2013, M.P. Mauricio Torres Cuervo (Relatoría Consejo de Estado, 2016, p.1).

4 Factor competencia de la Procuraduría General de la Nación: Conoce de la sanción disciplinaria consistente en destitución; la que origina una falta temporal que da lugar a remplazo.

En este asunto, existe un conflicto en la actualidad, toda vez que la Corte Constitucional ha declarado exequible el artículo 44 de la Ley 734 de 2002 (Secretaría del Senado, 2016, p.2), que consagra la destitución e inhabilidad general como sanción, así lo reiteró en la sentencia C-500 del 16 de julio de 2014 (Secretaría del Senado, 2016) cuando sustenta:

7.4.3. La decisión adoptada en la sentencia C-028 de 2006 implica que el legislador puede, sin desconocer la Constitución y las normas internacionales, atribuir a los organismos de control del Estado competencias disciplinarias que conduzcan incluso a la imposición de sanciones de destitución e inhabilidad general de los servidores públicos, cuando con su comportamiento se afecte la moralidad pública, la imparcialidad de la administración, el imperio de la ley y, por ello, se comprometa la adecuada lucha contra la corrupción. El respeto de tales reglas de conducta exige el "adecuado comportamiento del servidor público respecto de las formalidades y finalidades que se derivan del principio del respeto al bloque de legalidad (...)"[87] (Negrillas no son del original). Es precisamente en esa dirección, que se encuentran los supuestos cuya ocurrencia da lugar a imponer las sanciones previstas en el numeral $1^{\circ}$ del artículo 44 de la Ley 734 de 2002 (p.1).

La posición adoptada por la Corte Interamericana de Derechos Humanos, cuando la sanción de destitución e inhabilidad general inmediata se torna inoperante para los cargos derivados directamente de elección popular, al tenerse en cuenta la suspensión de la medida hasta que se termine el periodo del candidato electo, tal como lo estableció la Corte Interamericana de Derechos Humanos en las medidas cautelares del caso del alcalde mayor de la ciudad de Bogotá D.C., Gustavo Francisco Petro Urrego; donde se solicitó la protección inmediata ante la violación a los derechos a la integridad personal (artículo 5), a las garantías judiciales derechos fundamentales (artículo 8), a los derechos políticos (artículo 23), al derecho a la igualdad ante la ley (artículo 24) y a la protección judicial (artículo 25) de la Convención Americana sobre Derechos Humanos (en adelante "La Convención Americana") decisión esta tomada a favor del citado alcalde que por vía de medida cautelar de protección judicial (artículo 25) que ordenó suspender la destitución del señor Acalde Mayor. De ahí que la Corte Constitucional en Sentencia T-976 de 2014 se pronuncia al respecto de las medidas cautelares ordenadas por la Comisión Interamericana de Derechos Humanos (Relatoría Corte Constitucional, 2014) al indicar lo siguiente:

La Comisión Interamericana ha establecido que las medidas cautelares tienen un carácter tutelar y cautelar. El primero pretende evitar un daño irreparable y preservar el ejercicio de los derechos humanos, mientras que el segundo busca preservar una situación jurídica mientras esté siendo considerada por la CIDH. De tal forma que el objeto y fin de las medidas cautelares es el de "asegurar la integridad y la efectividad de la decisión de fondo y, de esta manera, evitar que se lesionen los derechos alegados, situación que podría hacer inocua o desvirtuar el efecto útil (effetutile) de la decisión final”. Por su parte, cabe aclarar que la Corte Interamericana, con el mismo carácter cautelar y tutelar, emite medidas provisionales y con base en las mismas condiciones de gravedad, urgencia e irreparabilidad del daño (p.1).

La misma sentencia indica la incorporación de la medida cautelar al ordenamiento jurídico interno así:

La Corte Constitucional ha sido constante en reconocer que las medidas cautelares son actos jurídicos adoptados por un organismo internacional de naturaleza cuasijurisdiccional, mediante el cual se conmina al Estado a tomar, en el menor tiempo posible las medidas necesarias para cesar la amenaza de un derecho (p.1). 
Unido a lo anterior, los artículos 229 y siguientes de la Ley 1437 de 2011 (2016, p.6), consagran las medidas cautelares y el procedimiento a seguir con el fin de suspender provisionalmente la sanción; así mismo, en Sentencia SU-355 del 11 de junio de 2015 magistrado ponente. Mauricio Gonzales Cuervo (Relatoría Corte Constitucional, 2016). Procede la tutela en forma excepcional cuando con la aplicación de las normas del estatuto CPACA no proporcione una protección oportuna de los derechos fundamentales o cuando el contenido o interpretaciones no provean un amparo integral de tales garantías. El caso "Petro" a pesar de ser análogo al artículo 134 de la Constitución Política de Colombia en cuanto a la aplicación de la figura de la silla vacía, da algo de luz a una posible garantía de protección cautelar previa por parte de la Corte Interamericana de Derechos Humanos en cuanto a las restricciones de los derechos políticos que contempla la convención.

\section{De la falta susceptible o no de remplazo}

1. Por muerte: Se tiene que la muerte produce efectos de extinción de la acción penal contenida en el numeral $1^{\circ}$ del artículo 82 del Código Penal Colombiano (Secretaría del Senado, 2016); en el caso que ocurra la muerte de un elegido popularmente que estuviera sancionado con falta temporal o absoluta que no da lugar a remplazo, la silla vacía sufre una mutación jurídica y pasa a ser en forma automática una falta temporal que da lugar a remplazo y se llama al siguiente de la lista por el mismo partido para que ocupe la curul vacante.

2. Circunstancias que implique que no pueda ser reemplazado: Un miembro elegido a una corporación pública; por estar incurso en proceso penal o condena relacionada con los delitos del artículo 134 Superior, no será reemplazado el elegido; aparece la silla vacía de carácter temporal; pero si se da una condena penal por este delito pasará a ser una falta absoluta.

3. Las exenciones de inconstitucionalidad: Por violación al artículo 23 de la Convención Americana de derechos Humanos (ONU, 2016, p.1) y /o que se solicite la medida cautelar preventiva expedida por la corte interamericana de Derechos Humanos, no genera silla vacía de carácter temporal ni absoluta para la curul, el elegido debe asistir a la plenaria como cualquier otro diputado hasta que su situación jurídica quede en firme.

4. La Renuncia justificada de un miembro: De la corporación pública presentada a la corporación es una falta absoluta que da lugar a remplazo, pero en el eventual caso si se comprueba que la renuncia obedeció porque había sido vinculado formalmente en Colombia o en el extranjero por delitos de pertenencia, promoción o financiación a/o por grupos armados ilegales, actividades de narcotráfico, dolosos contra la administración pública; contra los mecanismos de participación democrática ni por delitos de lesa humanidad; opera la silla vacía de curul por falta absoluta que no da lugar a remplazo.

5. Con la orden de Captura: Por delitos de pertenencia, promoción o financiación a/o por grupos armados ilegales, actividades de narcotráfico, dolosos contra la administración pública; contra los mecanismos de participación democrática ni por delitos de lesa humanidad. Opera la silla vacía de curul por falta absoluta que no da lugar a remplazo.

6. Por circunstancias excepcionales: Situación jurídica en la aplicación de figura de "la silla vacía" Para este tipo de caso se presenta en el caso fortuito o fuerza mayor. Por ejemplo: la enfermedad grave, en tratándose de cáncer terminal, el congresista convaleciente puede ausentarse legalmente por estar excusado; como lo dispone el numeral 3 del artículo 42 de la Ley 5 de 1992.

7. En referencia a las dos curules adicionadas en el Congreso de la República: Para el candidato a la presidencia y vice presidencia vencido en las elecciones, por derecho personal en el senado y en la 
cámara de representantes, si alguno no lo acepta, no hay lista, por tanto, continuaría el otro partido, pero si fue vencido en segunda vuelta, donde hay solo dos candidatos, se aplica la silla vacía en la curul que no fue aceptada.

8 Los periodos de elección son de cuatro años. En los cuerpos colegiados y la aplicación de la silla vacía puede afectar el quórum, por ello, el artículo 134 Superior, ordena al Consejo Nacional Electoral a convocar nuevamente a elecciones si faltan más de veinticuatro (24) meses, en caso contrario, como solución se contabiliza el número de integrantes sin contar las vacantes.

\section{Análisis cualitativo}

La Constitución Política de Colombia consagra el derecho político de libre representación, es por ello, que el Estado Colombiano se encuentra obligado a realizar periódicamente elecciones libres, las cuales dan como resultado la elección de ciudadanos para representar al pueblo en las corporaciones públicas de la rama ejecutiva y legislativa.

El derecho político de libre representación se encuentra consagrado en artículo 25 del Pacto Internacional de Derechos Civiles y Políticos (ONU, 2016), el cual consagra que todos los ciudadanos gozarán sin restricciones indebidas; igualmente lo confirma la Convención Americana de Derechos Humanos en el artículo 23 (ONU, 2016), tratados internacionales ratificados y vigentes en el sistema legal colombiano, pertenecientes al bloque de constitucionalidad por el artículo 93 Superior (Secretaría del Senado, 2016, p.3) y del que se atiende su obligatorio cumplimiento según la convención de Viena artículo 26 que consagra el "pacta sunt servanda" debidamente ratificado en la ley 32 de 1985 (MINTIC, 2016, p.8).

Lo que significa, que el derecho político de libre representación al que tiene derecho todo ciudadano debe ser respetado por el Estado Colombiano, y la representación se refiere a las ramas del poder ejecutivo y legislativo respectivamente. En este sentido, la Constitución Política de 1991 (2016) ha organizado al Estado en Corporaciones las cuales deben ser suplidas por ciudadanos elegidos por elección popular; es importante volver a recalcar que el derecho debe ser ejercido por el pleno de la ciudadanía sin ningún tipo de restricciones y indebidas.

Por su parte el artículo 134 de la Carta (Secretaría del Senado, 2016, p.5), prevé una figura de silla vacía que puede afectar a las corporaciones de los cuerpos colegiados en lo referente al quórum deliberatorio o decisorio, a tal punto que ordena al Consejo Nacional Electoral realizar elecciones por la afectación del mismo si hacen falta más de 24 meses para la terminación del período; asimismo indica la manera como se debe calcular la mayoría en las corporaciones sin contar las sillas vacías. Lo que es una violación de una restricción del derecho de libre representación en los cuerpos colegiados que existen en Colombia, vulnerando sustancialmente este derecho.

La silla vacía en la curul se debe aplicar por parte de los cuerpos colegiados bajo los parámetros establecidos en el artículo 134 de la Carta (Secretaría del Senado, 2016, p.5), taxativamente se consagran los momentos en que se deben aplicar, pero se observa que los vacíos jurídicos que puedan existir deben ser suplidos con la silla vacía; es así, como para las faltas temporales que dan lugar a reemplazó existen solamente dos momentos en los cuales aplicarla, lo demás se sobre entiende que la figura de la silla vacía es la regla general, igualmente ocurre con las faltas absolutas que dan lugar a remplazo donde existen cinco momentos. Así las cosas, la vacante de la curul que no da lugar a sustitución, se aplica por falta temporal o absoluta en los siguientes casos: 
Tabla 3. Las faltas temporales y absolutas que no dan lugar a remplazo

\begin{tabular}{|c|c|}
\hline Falta temporal & Falta absoluta \\
\hline $\begin{array}{l}\text { 1. Contra quienes se profiera orden de captura por } \\
\text { delitos comunes relacionados con pertenencia, promoción o } \\
\text { financiación a grupos armados ilegales o actividades de } \\
\text { narcotráfico; dolosos contra la administración pública; contra } \\
\text { los mecanismos de participación democrática; y de Lesa } \\
\text { Humanidad. }\end{array}$ & $\begin{array}{l}\text { 1. Los condenados por delitos comunes relacionados con } \\
\text { pertenencia, promoción o financiación a grupos armados ilegales. }\end{array}$ \\
\hline \multirow[t]{7}{*}{$\begin{array}{l}\text { 2. Lo no consagrado como falta temporal que da lugar a } \\
\text { remplazo. }\end{array}$} & Los condenados por delitos por actividades de narcotráfico; \\
\hline & $\begin{array}{l}\text { 3. Los condenados por delitos dolosos contra la administración } \\
\text { pública. }\end{array}$ \\
\hline & $\begin{array}{l}\text { 4. Los Condenados por delitos contra los mecanismos de } \\
\text { participación democrática. }\end{array}$ \\
\hline & 5. Los condenados por delitos de Lesa Humanidad. \\
\hline & 6. Quienes renuncien habiendo sido vinculados formalmente en \\
\hline & Colombia a procesos penales por la comisión de los anteriores delitos. \\
\hline & 7. Lo no consagrado como falta absoluta que da lugar a remplazc \\
\hline
\end{tabular}

Fuente: elaboración propia

Para el resultado obtenido se reitera la línea de investigación alusiva al Positivismo de Hart como corriente filosófico jurídica basándose en la aplicación de la regla de interpretación y argumentación al contener directrices aplicativas para el operador judicial para que tome una decisión que resuelva el caso al establecer un orden jurídico y un sistema de aplicación que se aparte de un simple silogismo que brinda una técnica ordenada de factores que se reflejan en la siguientes tablas para entender mejor el cumplimiento de lo investigado y que conllevó al resultado conclusivo.

Ahora bien como los artículos 112, 134 de la Constitución Política y el artículo 23 de la Convención Interamericana de Derechos Humanos cumple los criterios de la regla de interpretación jurídica de Hart; ello permite evidenciar que efectivamente la regla general es la aplicación de la silla vacía, ya que lo que no se encuentra consagrado como falta temporal o absoluta susceptible a remplazo debe ser llenado con la vacante de la curul, lo que es una restricción indebida del derecho político de libre representación consagrado en la constitución política parte dogmática y los convenios y tratados internacionales existentes debidamente ratificados por Colombia.

\section{Conclusiones}

1. La figura de la silla vacía para la curul no susceptible a remplazo, existe en el sistema legal colombiano en el artículo 134 de la Constitución Política de 1991 (Secretaría del Senado, 2016) y es aplicable como regla general cuando no se cumplan los requisitos existentes para la falta temporal o absoluta que da lugar a remplazo, lo que trae como consecuencia jurídica que el constituyente al expedir la consagración integrada del mencionado artículo ha vulnerado el derecho político de libre representación popular consagrado en la parte dogmática de la Carta al contraponerse con el artículo 23 de la Convención Americana de Derechos Humanos traídos por el bloque de constitucionalidad. 
2. Taxativamente se determinaron las faltas temporales que dan lugar a remplazo y son: la licencia de maternidad, la medida de aseguramiento privativa de la libertad por delitos diferentes a los mencionados en el artículo 134 de la Constitución Política de Colombia. Así mismo, las faltas absolutas que dan lugar a remplazo, como son: la muerte, la incapacidad física absoluta para el ejercicio del cargo, la declaración de nulidad de la elección, la renuncia justificada y aceptada por la respectiva corporación, la sanción disciplinaria consistente en destitución, la pérdida de investidura, los condenados por delitos diferentes a los mencionados en el mencionado artículo.

3. No se aplica la figura de la silla vacía en la curul que da lugar a remplazo por presentase falta temporal o absoluta llamando a ocupar la curul el siguiente de la lista por el mismo partido solamente cuando se presente por licencia de maternidad, medida de aseguramiento privativa de la libertad por delitos distintos a los mencionados en el artículo 134 Superior, muerte, incapacidad física absoluta para el ejercicio del cargo, declaración de nulidad de la elección, renuncia justificada y aceptada por la respectiva corporación, sanción disciplinaria consistente en destitución y pérdida de investidura.

4. Se aplica la figura de la silla vacía para la curul del titular elegido por presentarse falta temporal o absoluta que no da lugar a remplazo por vinculación o condena en los procesos penales por delitos mencionados en el artículo 134 de la Carta, la renuncia de quien se encuentre vinculado formalmente en Colombia a procesos penales por la comisión de los anteriores delitos mencionados.

5. El artículo 112 de la Carta contempla la creación de dos (2) curules adicionales para el Congreso de la República; una (01) para el Senado y una (01) para la Cámara de Representantes, como derecho personal de los candidatos vencidos en las elecciones a la Presidencia y vicepresidencia de la República, cuando son vencidos en primera o en segunda vuelta y que el candidato vencido no acepte se aplica la figura de la silla vacía al senado o a la Cámara de Representantes.

6. otra consecuencia jurídica en la aplicación de la silla vacía sustentada en el artículo 134 de la Constitución Política de Colombia y dirigida a detallar los criterios de aplicación de las faltas temporales o absolutas que no dan lugar a remplazo en los cuerpos colegiados de elección popular, recae en los partidos políticos como un castigo a al no tener estos el debido cuidado al momento de otorgar el aval sus candidatos al momento de hacer su inscripción del candidato o lista previo el aval, dado que no podrá presentar candidatos a esa corporación para la próxima elección y además si faltaren 18 meses o menos no podrá presentar la terna alguna, de ello hace alusión la Ley 1475 de 2011 en el artículo 12 ordinal $6^{\circ}$ (alcaldiabogotá.gov.co, 2013).

7. La representación popular es encarnada en la persona física, material, es tangible, impregnada de respeto, honor y dignidad, y la figura de la silla vacía es abstracta, antagónica por ser intangible, carente de representación de la voluntad del pueblo que elige a sus representantes, al punto que el legislador estimó como regla general la aplicación de las sillas vacías, dejando de lado soluciones a los diversos problemas de representación que se generan por esta figura abstracta.

8. La aplicación de la figura de la silla vacía en los cuerpos colegiados de elección popular trae como consecuencia jurídica la posible lesión de quorum deliberatorio y decisorio, siendo necesario que se convoque a nuevas elecciones si faltaren más de 24 meses o si no se tomaran decisiones con el número de asistentes; en caso contrario se continua igual con el número de miembros sin contar las vacantes.

9. Se encontró un posible caso análogo de aplicación cautelar por parte de la Corte Interamericana de Derechos Humanos para protección al Derecho de ser elegido y de restricción de Derechos políticos, en cuanto al caso "Petro" que a pesar de ser diferente al artículo 134 de la Constitución Política de Colombia en cuanto a la aplicación de la figura de la silla vacía se refiere, da algo de luz a un camino de 
protección cautelar previo, instaurando la respectiva demanda de vulneración del Derecho Fundamental de ser elegido, igualdad ante la Ley y protección de la restricción de derechos políticos contra el Estado Colombiano.

10. Se encontró un vacío jurídico en el artículo 134 de la Constitución Política de Colombia al no contemplar la exista de una circunstancia excepcional como es por fuerza mayor o caso fortuito, que permitiera dar aplicación de la figura de la silla vacía como una falta temporal que no da lugar a remplazo por estar debidamente excusado el miembro de la corporación colegiada al ausentarse legalmente de su curul; como lo dispone el numeral 3 del artículo 42 de la Ley 5 de 1992.

11. Por último en cuanto a una posible solución a la vulneración del derecho político de libre representación popular, se propone exhortar al legislador que elimine la figura de la silla vacía por ser contraria a la disposición supraconstitucional contenida en el artículo 23 de la Convención Americana de Derechos Humanos; armonizando de esta manera el Derecho Interno con la Disposición Internacional.

\section{Referencias bibliográficas}

Alcaldía Mayor de Bogotá. (2016). Decreto 126 de 2010. Recuperado de http://www.alcaldiabogota.gov. co/sisjur/normas/Norma1.jsp?i=38664

Alcaldía Mayor de Bogotá. (2016). Decreto 1222 de 1986. Recuperado de http://www.alcaldiabogota.gov. co/sisjur/normas/Norma1.jsp?i=6100

Alcaldía Mayor de Bogotá. (2016). Decreto 1538 de 2005. Recuperado de http://www.alcaldiabogota.gov. co/sisjur/normas/Norma1.jsp?i=16540

Alcaldía Mayor de Bogotá. (2016). Ley 57 de 1887. Recuperado de http://www.alcaldiabogota.gov.co/ sisjur/normas/Norma1.jsp?i=39535

Alcaldía Mayor de Bogotá. (2016). Ley 95 de 1890. Recuperado de http://www.alcaldiabogota.gov.co/ sisjur/normas/Norma1.jsp?i=12387

Alcaldía Mayor de Bogotá. (2016). Ley 153 de 1887. Recuperado de http://www.alcaldiabogota.gov.co/ sisjur/normas/Norma1.jsp?i=15805

Brito, F. (2011). Pérdida de Investidura de los Congresistas Procedimiento para declararla. Bogotá D.C. Ediciones IEMP.

Consejo de Estado (2016). Proceso 19001233300320150049601 . Recuperado de http://avancejuridico. com/EIEspectador/CE11.pdf

ConsejodeEstado(2016).Proceso41001233300020130033701. Recuperadodehttps://www.google.com. $\mathrm{co} /$ search?sclient $=$ psy-ab\&rlz=1C1HLDY_esC0714C0714\&biw $=1440 \& b i h=794 \&$ noj $=1 \& q=$ sentencia+41001233300020130033701\&oq=sentencia+41001233300020130033701\&gs_l=se rp.3...3237.3237.1.4911.1.1.0.0.0.0.122.122.0j1.1.0.......1c.1.64.serp..0.0.0.i5y7dyE1RAg

Consejo de Estado (2016). Proceso №11001-03-28-000-2011-00068-00 del 6 de mayo de 2013. Recuperado de http://190.24.134.114:8080/WebRelatoria/ce/index.xhtml

Corte Constitucional. (2016). Sentencia C-254A de 2012. Recuperado de http://www.corteconstitucional. gov.co/RELATORIA/2012/C-254A-12.htm 
Corte Constitucional. (1993). Sentencia C - 532 de 1993. Recuperado de http://www.corteconstitucional. gov.co/relatoria/1993/C-532-93.htm

Corte Constitucional. (1992). Sentencia No. T-406/92. Recuperado de http://www.corteconstitucional. gov.co/relatoria/1992/t-406-92.htm

Corte Constitucional. (2016). Sentencia C-458 de 2015. Recuperado de http://www.corteconstitucional. gov.co/RELATORIA/2015/C-458-15.htm

Corte Constitucional. (2016). Sentencia C-500 de 2014. Recuperado de http://www.secretariasenado. gov.co/senado/basedoc/c-500_1914.html\#inicio

Corte Constitucional. (2010). Sentencia C-828/10. Recuperado de http://www.corteconstitucional.gov. co/RELATORIA/2010/C-828-10.htm

Corte Constitucional. (2016). Sentencia SU-355 de 2015. Recuperado de http://www.corteconstitucional. gov.co/relatoria/2015/SU355-15.htm

Corte Interamericana de Derechos Humanos (2014). MC 374/13 Gustavo Francisco Petro Urrego. Recuperado de http://www.oas.org/es/cidh/decisiones/pdf/2014/MC374-13-ES.pdf

Dahl, R. (12,2004) La Democracia. Revista POST Data. Volumen 10, ISSN 1515-209X, (págs. 11-55) recuperado de http://sociologiapolitica.sociales.uba.ar/files/2013/09/Dahl-POstdata.pdf

González, N. (1998). Los derechos Humanos en la Historia. Barcelona España: Edición Universidad de Barcelona.

Hart, H.L.A (1998). El concepto de derecho, Traducción Genaro R. Carrió. Buenos Aires: Editorial Abeledo Perrot.

Martos F. (2005). Auxiliares Administrativos del Cabildo Insular de Gran Canaria. Segunda edición. Gran Canaria: Editorial MAD.

Ministerio de Salud y Protección Social (2016). la circular externa Conjunta 000013 del 12 de marzo de 2012. Recuperado de https://www.minsalud.gov.co/Normatividad_Nuevo/Clircular\%20 Externa\%20Conjunta\%200013\%20de\%202012.pdf

Ministerio de las Tecnologías de la Información y las Comunicaciones. (2016). Ley 32 de 1985. Recuperado de http://www.mintic.gov.co/portal/604/articles-3718_documento.pdf

Organización de las Naciones Unidas. (1966). Pacto Internacional de los Derechos Civiles y Políticos. Recuperado de http://www.ohchr.org/SP/Professionallnterest/Pages/CCPR.aspx

Organización de las Naciones Unidas. (1969). Convención Americana sobre Derechos Humanos. Recuperado de http://www.hchr.org.co/documentoseinformes/documentos/html/pactos/conv_ americana_derechos_humanos.html

Rodríguez, C. (2005). La Decisión Judicial. El debate Hart - Dworkin. Bogotá D.C. Colombia: Siglo del Hombre Editores. 
Secretaría del Senado. (2016). Código Administrativo y de lo Contencioso Administrativo. Recuperado de http://www.secretariasenado.gov.co/senado/basedoc/ley_1437_2011.html

Secretaría del Senado. (2016). Código Civil. Recuperado de http://www.secretariasenado.gov.co/senado/ basedoc/codigo_civil.html

Secretaría del Senado. (2016). Código Electoral. Recuperado de http://www.secretariasenado.gov.co/ senado/basedoc/decreto_2241_1986.html

Secretaría del Senado. (2016). Código Penal Colombiano. Recuperado de http://www.secretariasenado. gov.co/senado/basedoc/ley_0599_2000.html

Secretaría del Senado. (2016). Código Procedimiento Penal. Recuperado de http://www.secretariasenado. gov.co/senado/basedoc/ley_0906_2004.html

Secretaría del Senado. (2016). Código de Régimen Municipal. Recuperado de http://www.secretariasenado. gov.co/senado/basedoc/decreto_1333_1986.html

Secretaría del Senado. (2016). Constitución Política de Colombia. Recuperado de http://www. secretariasenado.gov.co/senado/basedoc/constitucion_politica_1991.html

Secretaría del Senado. (2016). Ley 5 de 1992. Recuperado de http://www.secretariasenado.gov.co/index. php/ley-5-de-1992

Secretaría del Senado. (2016). Ley 56 de 1993. Recuperado de http://www.secretariasenado.gov.co/ senado/basedoc/ley_0056_1993.html

Secretaría del Senado. (2016). Ley 136 de 1994. Recuperado de http://www.secretariasenado.gov.co/ senado/basedoc/ley_0136_1994.html

Secretaría del Senado. (2016). Ley 144 de 1994. Recuperado de http://www.secretariasenado.gov.co/ senado/basedoc/ley_0144_1994.html

Secretaría del Senado. (2016). Ley 361 de 1997. Recuperado de http://www.secretariasenado.gov.co/ senado/basedoc/ley_0361_1997.html

Secretaría del Senado. (2016). Ley 617 de 2000. Recuperado de http://www.secretariasenado.gov.co/ senado/basedoc/ley_0617_2000.html

Secretaría del Senado. (2016). Ley 734 de 2002. Recuperado de http://www.secretariasenado.gov.co/ senado/basedoc/ley_0734_2002.html

Secretaría del Senado. (2016). Ley 762 de 2002. Recuperado de http://www.secretariasenado.gov.co/ senado/basedoc/ley_0762_2002.html

Secretaría del Senado. (2016). Ley 1468 de 2011. Recuperado de http://www.secretariasenado.gov.co/ senado/basedoc/ley_1468_2011.html

Secretaría del Senado. (2016). Ley 1474 de 2011. Recuperado de http://www.secretariasenado.gov.co/ senado/basedoc/ley_1474_2011.html 
Secretaría del Senado. (2016). Ley 1523 de 2012. Recuperado de http://www.secretariasenado.gov.co/ senado/basedoc/ley_1523_2012.html

Secretaría del Senado. (2016). Ley 1551 de 2012. Recuperado de http://www.secretariasenado.gov.co/ senado/basedoc/ley_1551_2012.html

Tamayo, R. y Hart, H.L.A. (2000). Post Scritum Al Concepto del Derecho. México D.F: Universidad Autónoma de México.alcaldiabogotá.gov.co. (01 de 01 de 2013). Recuperado el 4 de febrero de 2017, de normas: http://www.alcaldiabogota.gov.co/sisjur/normas/Norma1.jsp?i=43332

Congreso de la Republica. (21 de 08 de 2014). claudia-lopez.com/wp-content/uploads/2014/08/ PAL-011-14-Silla-Vacia.pdf. Obtenido de https://www.claudia-lopez.com/wp-content/ uploads/2014/08/PAL-011-14-Silla-Vacia.pdf

Corte Constitucional . (16 de Febrero de 2015). Corte Constitucional, relatoría . Obtenido de http://www. corteconstitucional.gov.co/relatoria/t-066-15 htm

Corte Constitucional . (15 de Enero de 2016). Constitución Política de Colombia. Corte Constitucional . Obtenido de http//www.corteconstitucional.gov.co/inicio/constitucion

Nohlen , D., Zovatto, D., Orozco, J., \& Thompson , J. (1998). Tratado de derecho electoral comparado de America Latina. México : Fondo de cultura económica .

SlideShare. (01 de enero de 2010). SlideShare. Recuperado el 04 de febrero de 2017, decida del imperio romano y edad media: http://es.slideshare.net/evaavila/cada-del-imperio-romano-y-edad-media 